Working Paper in Economics No. 786

\title{
The Climate Decade: Changing Attitudes on Three Continents
}

Fredrik Carlsson, Mitesh Kataria, Alan Krupnick, Elina Lampi, Åsa Löfgren, Ping Qin, Thomas Sterner, Xiaojun Yang*

Department of Economics, January 21 


\title{
The Climate Decade: Changing Attitudes on Three Continents
}

\author{
Fredrik Carlsson, Mitesh Kataria, Alan Krupnick, Elina Lampi, Åsa Löfgren, Ping Qin, \\ Thomas Sterner, Xiaojun Yang*
}

\begin{abstract}
Using identical surveys a decade apart, we examine how attitudes and willingness to pay (WTP) for climate policies have changed in the United States, China, and Sweden. All three countries exhibit an increased willingness to pay for climate mitigation. Ten years ago, Sweden had a larger fraction of believers in anthropogenic climate change and a higher WTP for mitigation, but today the national averages are more similar. Although we find convergence in public support for climate policy across countries, there is considerable divergence in both WTP and climate attitudes within countries. Political polarization explains part of this divergence.
\end{abstract}

Keywords: Climate change, willingness to pay, climate policy attitudes, political polarization, multicountry, China, United States, Sweden

JEL Classification: Q51, Q54

\footnotetext{
* Carlsson: Department of Economics, University of Gothenburg, Box 640, SE-40530 Gothenburg, Sweden (email: fredrik.carlsson@economics.gu.se); Kataria: Department of Economics, University of Gothenburg, Box 640, SE-40530 Gothenburg, Sweden (email: mitesh.kataria@economics.gu.se); Krupnick: Resources for the Future, 1616 P St., NW, Washington, DC 20036, USA (email: Krupnick@rff.org); Lampi: Department of Economics, University of Gothenburg, Box 640, SE-40530 Gothenburg, Sweden (email: elina.lampi@economics.gu.se); Löfgren, Department of Economics, University of Gothenburg, P.O. Box 640, S40530 Gothenburg, Sweden (email: asa.lofgren@economics.gu.se); Qin: School of Applied Economics, Renmin University of China, China (email: pingqin@ruc.edu.cn); Sterner: Department of Economics, University of Gothenburg, Box 640, SE-40530 Gothenburg, Sweden (email: thomas.sterner@economics.gu.se); Yang: School of Public Policy and Administration, Xi'an Jiaotong University, China (email: xjyang@mail.xjtu.edu.cn). The authors acknowledge financial support from the Mistra Carbon Exit research program (the Swedish Foundation for Strategic Environmental Research) and Swedish Energy Agency project 46167-1. We have received valuable comments from two anonymous reviewers, participants of the RWI Empirical Environmental Economics Workshop in Essen, and seminar participants at Umeå University and University of Gothenburg.
} 


\section{Introduction}

The last decade can surely be called the Climate Decade. High temperatures and carbon dioxide $\left(\mathrm{CO}_{2}\right)$ emissions have set new records, but effective political action has proven elusive. Despite strong scientific evidence of the risks of continued warming and substantial progress with renewable energy, little overall progress has been made toward a coherent set of global climate policies. The only signature result has been the 2015 Paris Agreement. While many individual countries and regions have implemented various policies, ranging from energy efficiency standards to carbon pricing, the scope is often too narrow, and policies remain too weak to deliver on the objectives of the Paris Agreement (World Bank, 2019). There are many reasons why policies have or have not been implemented and why there is a lack of stricter global agreements. One important reason is that climate change has the characteristics of an international social dilemma, where countries have to make sacrifices for the collective good (i.e., the global climate system) but, given ample free-riding possibilities, are hesitant to do so. Since mitigating climate change involves economic costs today with mainly collective benefits in the future, political leaders in democratic countries face challenges in legitimizing such costs to their electorates. A vast body of literature explains the difficulty in agreeing on top-down global policies and effort-sharing rules (see, e.g., Keohane, 2011).

Our study examines whether the increasing warning signs over the last decade that the earth is warming are matched by citizens' demand for stronger policy action. Specifically, we address three important questions: (i) how much citizens are willing to pay for reducing $\mathrm{CO}_{2}$ emissions, (ii) whether citizens' willingness to pay (WTP) has changed over the past decade, and (iii) whether political polarization has increased or decreased when it comes to opinions on climate policies and preferences for decreasing $\mathrm{CO}_{2}$ emissions. We do this in three key geographies: the United States, China, and Europe (represented in this case by Sweden).

To answer these three questions, we estimate WTP across the three continents in both 2009 and 2019, using the same survey design and the same method (contingent valuation). This comparison with consistent methodology provides a unique opportunity to investigate whether attitudes and WTP have changed both within each country and across the three countries over the decade since the Copenhagen Accord. To our knowledge, this kind of comparison over time has not been undertaken before. 
In our comparative study from 2009 (Carlsson et al., 2012), we found that Americans and Chinese citizens were willing to give up about the same percentage of their income for reducing carbon emissions (controlling for income differences), while Swedes were willing to give up a larger fraction of their income. A larger share of Americans were skeptical of climate change and the responsibility of human activities, compared with the Chinese and Swedes. Since that study, a number of cross-country studies have been conducted, several of which include comparisons of US and Chinese citizens (see, e.g., Jamelske et al., 2015; Ziegler, 2017; Schwirplies, 2018; Winden et al., 2018).

Attitudinal changes over time could result from many causes, including increasing political polarization. In the United States, the climate debate has long been polarized between Republicans and Democrats, even well before 2009 (Malka et al., 2009), and in Sweden, signs of increased polarization between sympathizers of different political parties regarding environmental and climate issues have emerged over the last decade (Martinsson and Weissenbilder, 2019). Guber (2013) warns that polarization allows political parties to frame the debate over climate change, with troubling implications. Political polarization could lead to political inaction or weak policies and shift the focus from climate to ideology (Hoffman, 2011). Notably, the United States under the Trump administration has withdrawn from the Paris Agreement, although the incoming Biden administration has announced that the country will immediately rejoin. The election outcome may well be one of the most significant factors in addressing global climate change during the coming decade.

While previous literature has investigated the relationship between WTP for climate policies and political affiliation (Ziegler, 2017; Hornsey et al., 2016; Hornsey et al., 2018) and attitudes and beliefs (Schwirplies, 2018), we instead investigate political polarization related to climate policy and whether this relationship has changed during the past decade. The importance of political ideology in affecting willingness to pay for climate change mitigation does not apply only to Americans. As shown by Hornsey et al. (2016) in a meta-analysis of 171 academic studies across 56 nations, factors such as education, gender, subjective knowledge about climate change, and experience of extreme weather events seem to be less important to explain belief in climate change than ideology, worldview, and political orientation. This result seems particularly important in light of the increased political polarization and the rise of populist parties in the United States and Europe over the last decade (Westfall et al., 2015; Muis and 
Immerzeel, 2017). Kousser and Tranter (2018) argue that in the presence of political polarization, when political leaders disagree on issues such as climate, the electorate also becomes more polarized.

Our results show that 10 years ago, Sweden stood out, with a larger fraction of believers in anthropogenic climate change and a higher WTP for mitigation. Over the last decade, there have been greater increases in both of these measures in China and the United States, so today the national averages are much more similar. These results are in line with the picture given by individual studies conducted in these countries during the last decade. In particular, there seems to be a trend that Chinese citizens have increased their WTP over time. For example, in the 2018 study by Winden and colleagues, Chinese WTP was more than twice that of their US counterparts (in purchasing power parity terms). Notably, the levels of WTP in 2019 in the three different countries compare closely to conventional measures of the social cost of carbon in China and the United States and to current carbon taxes in Sweden. This is further discussed in both the results and the conclusions sections.

We also find that there is a considerable heterogeneity within the countries, with respect to both attitudes and, more importantly, political affiliation. In both the United States and Sweden, we find a left-right difference in WTP. In the United States, the average WTP of self-identified Republicans is significantly lower than that of people affiliated with other parties, especially Democrats. This is clearly in line with the findings of previous studies, such as Ziegler (2017). Schwirplies (2018) investigates China and the United States (as well as Germany) and finds that political attitudes and socioeconomic characteristics are the main sources of cross-country heterogeneity. Hornsey and colleagues (2018) find that the correlation between climate skepticism and ideology is both stronger and more consistent in the United States than in 24 other countries. In China, those who are members of the Communist Party have a higher WTP, confirming the previous findings by Ziegler (2017).

Finally, the political divide between Republicans and Democrats in terms of climate policy already existed in 2009, and we find sizable but statistically insignificant changes in polarization in the whole sample of US respondents. This is consistent with the studies on climate attitudes in the United States by Jon Krosnick (PPRG, 2018). Krosnick finds that the partisanship gap in climate beliefs between Republicans and Democrats has been essentially constant since 2011, although it has increased by a small percentage from 2009. However, in 
our study there is some evidence of increased polarization in the United States if we look at the number of respondents who are not willing to pay anything to decrease carbon dioxide emissions. We find that among self-identified Republicans, this share is large and stable over time, while the corresponding shares among Democrats and independents have significantly decreased further during the past decade. This is an indication of increased polarization between Republicans and others within this dimension (zero WTP). In Sweden, our results provide stronger evidence of increased polarization with respect to WTP for a stricter climate policy. We find an increasing polarization between left-wing and right-wing voters, and the share of right-wing voters with a zero WTP is significantly larger than the corresponding shares of other voters. Still, it should be noted that in both Sweden and the United States, there is still an overall increase in support for climate policy over the last decade.

The rest of the paper is organized as follows: In section II we describe the design of the studies in 2009 and 2019. In section III we present the results, and in section IV we discuss our findings and their implications.

\section{Survey Design}

To be able to rule out that any changes across time are not due to changes in the survey design, we used, as far as possible, the same survey in both 2009 and 2019. This comes at a potential cost because the standards for survey design have changed during the last 10 years. However, since the focus of the current study is on comparisons across time, this should not be of any major concern. One of the very few differences between the surveys is that the 2009 survey was longer than the 2019 survey. More specifically, the 2009 survey included a section at the end that was not relevant for the current study. ${ }^{1}$ Following are descriptions of the three segments of questions that were included in both the 2009 and 2019 surveys.

In the first segment, we asked general questions about climate change to establish the degree to which respondents are climate change deniers. We asked whether respondents believed that the world's average temperature has increased during the past 100 years, and if so, whether this increase has been caused by human behavior. We also asked whether respondents believed that climate change is inevitable or that there are actions that can reduce or stop it.

\footnotetext{
${ }^{1}$ The section at the end of the 2009 survey was reported in Carlsson et al. (2013), and analyzed respondents' preferences for how to divide the global costs to decrease $\mathrm{CO}_{2}$ emissions among different countries.
} 
In the second segment, we provided information about how different levels of global temperature increases would affect environmental outcomes sensitive to climate change, such as harvests, flooding, storms, and threatened ecosystems. This information was based on a set of UN Intergovernmental Panel on Climate Change (IPCC) reports from 2008. Furthermore, we gave the respondents the following information: "There are a small number of experts who disagree with the IPCC consensus, but because the IPCC represents the large majority of climate researchers, this survey will use information from the IPCC.” To keep the information as simple as possible and understandable for respondents without statistical literacy, we did not communicate any additional uncertainties. We explained that the temperature increase depends on the quantity of future global $\mathrm{CO}_{2}$ emissions. To limit the temperature increase to just $2^{\circ} \mathrm{F}$, $3^{\circ} \mathrm{F}$, or $4^{\circ} \mathrm{F}$, yearly $\mathrm{CO}_{2}$ emissions would need to be decreased from current levels. The information given to the respondents is shown in Table 1 . The respondents were given the information that $\mathrm{CO}_{2}$ reductions of 30,60 , and 85 percent correspond to temperature increases of $4^{\circ} \mathrm{F}, 3^{\circ} \mathrm{F}$, and $2^{\circ} \mathrm{F}$, respectively. In addition, we noted that if the world does not reduce emissions and continues with business as usual, the IPCC experts predict a temperature increase of more than $4^{\circ} \mathrm{F}$ between 2050 and 2100, which would most likely correspond to even larger changes in the global ecosystem, and most countries would be negatively affected. ${ }^{2}$

\footnotetext{
${ }^{2}$ The percentages and temperatures were the same in the 2009 and 2019 surveys, but to keep the time frame the same as in the 2009 survey (40 years), we changed the end year of payment from 2050 to 2060 in the 2019 survey.
} 
Table 1. The Effects of Temperature Increase on Harvests, Increased Flooding and Storms, and Threatened Ecosystems between 2050 and 2100

\begin{tabular}{|l|l|l|l|}
\hline $\begin{array}{l}\text { Global emissions } \\
\text { reduction }\end{array}$ & \multicolumn{1}{|c|}{$85 \%$ reduction } & \multicolumn{1}{|c|}{$60 \%$ reduction } & \multicolumn{1}{|c|}{$30 \%$ reduction } \\
\hline Temperature increase & $\begin{array}{l}2^{\circ} \mathrm{F} \text { increase } \\
\text { Harvests in countries } \\
\text { near the equator } \\
\text { decrease by 4\%-6\%. } \\
\text { Harvest } \\
\text { Harvests in countries } \\
\text { in the Northern } \\
\text { Hemisphere increase } \\
\text { by 1\%-3\%. }\end{array}$ & $\begin{array}{l}\text { Hearvests in countries } \\
\text { necrease by 10\%- } \\
\text { 12\%. Harvests in } \\
\text { countries in the } \\
\text { Northern Hemisphere } \\
\text { are unaffected. }\end{array}$ & $\begin{array}{l}4^{\circ} \text { F increase } \\
\text { Hearvests in countries } \\
\text { decrease by 14\%- } \\
16 \% \text {. Harvests in the } \\
\text { Northern Hemisphere } \\
\text { decrease by 0\%-2\%. }\end{array}$ \\
\hline $\begin{array}{l}\text { Increased flooding and } \\
\text { storms }\end{array}$ & $\begin{array}{l}\text { Small tropical islands } \\
\text { and lowland } \\
\text { countries, for } \\
\text { example Bangladesh, } \\
\text { experience increased } \\
\text { flooding and storms. }\end{array}$ & $\begin{array}{l}\text { Additional low-lying } \\
\text { areas in the } \\
\text { Americas, Asia, and } \\
\text { Africa experience } \\
\text { increased flooding } \\
\text { and storms. }\end{array}$ & $\begin{array}{l}\text { Populous cities face } \\
\text { increased flood risks } \\
\text { from rivers and ocean } \\
\text { storms. Existence of } \\
\text { small island countries } \\
\text { is threatened. }\end{array}$ \\
\hline Threatened ecosystems & $\begin{array}{l}\text { Sensitive ecosystems } \\
\text { such as coral reefs } \\
\text { and the Arctic } \\
\text { ecosystem are } \\
\text { threatened. }\end{array}$ & $\begin{array}{l}\text { Most coral reefs die. } \\
\text { Additional sensitive } \\
\text { ecosystems and } \\
\text { species around the } \\
\text { world are threatened. }\end{array}$ & $\begin{array}{l}\text { Sensitive and less } \\
\text { sensitive ecosystems } \\
\text { and species around } \\
\text { the world are } \\
\text { threatened. }\end{array}$ \\
\hline
\end{tabular}

After presenting this information, the survey included a set of attitudinal questions about how the respondent's own country should decrease $\mathrm{CO}_{2}$ emissions and whether it should reduce these emissions even if other countries do not. The segment ended with a cheap talk script, ${ }^{3}$ followed by three WTP questions asking the respondents to state their household's maximum monthly willingness to pay to decrease $\mathrm{CO}_{2}$ emissions by 30, 60, and 85 percent (in both surveys, the payment time frame was 40 years). The first WTP question asked respondents how much their household would be willing to pay for a 30 percent reduction compared with no reduction at all (business as usual). The second question asked respondents how much more their household would pay for a 60 percent reduction instead of the 30 percent reduction. The

\footnotetext{
${ }^{3}$ The cheap talk script read, "Before making your choices, please consider how an increased cost would affect your possibilities for buying other things. Previous studies of this kind have shown that people claim to be willing to pay more money than they actually would in a real situation. It is important to us that you answer the questions in this study as truthfully as possible.” As Johnston and colleagues. (2017) discuss, the use of cheap talk is potentially problematic, particularly if it affects the perceived consequentiality for some respondents. However, since the script was included in the study conducted in 2009, we decided to keep it in the 2019 study as well. It should be noted that respondents were told that the purpose of the study was to design better climate policies. We therefore have no reason to believe that respondents viewed our study as less consequential than other, similar types of studies, but we did not include any follow-up question on perceived consequentiality (Vossler et al., 2012) or vary the message regarding consequentiality of the survey (Meginnis et al., 2018; Zawojska et al., 2019).
} 
final WTP question asked them how much more their household would be willing to pay for an 85 percent reduction compared with the 60 percent reduction.

A payment card with 24 bids was used when eliciting WTP. The highest bid was \$220, and those who were willing to pay more than that could state their WTP in an open-ended payment question. Respondents who stated zero WTP were also asked all three WTP questions. In each WTP question, total monthly and yearly costs were shown to the respondents to make sure that they understood the consequence of their answers. The payment vehicle for obtaining the different reductions was increases in energy costs, such as through higher electricity and gasoline prices (adjusted for inflation). Respondents were also told that the costs of reducing $\mathrm{CO}_{2}$ emissions would be shared among the countries according to their current emissions. There were several reasons for using the payment card format. First, there was a clear risk of a poor bid-vector design for at least one country if we would use a closed-ended format, given the uncertainties about the underlying true WTP function. Second, respondents could be uncertain about their WTP, and a payment card format that allows for a wider range of response compared with a discrete choice format could therefore be preferred (Welsh and Poe, 1998). Finally, prior experience with administering both closed-ended and payment card questions in China (Krupnick et al., 2010) led us to favor the latter, based on performance of external scope tests.

The third (and final) segment of the survey included background questions for respondents, mainly about socioeconomic characteristics such as gender, age, education, occupation, and income.

The first study was conducted in November-December 2009. The Chinese survey was administered in four cities: Beijing, Nanning, Jiujiang, and Chonqging. Respondents were randomly selected using neighborhood-based databases, and they were invited to take the survey in special rooms with laptops. These cities were chosen by the Chinese government's Ministry of the Environment (now Ministry of Ecology and Environment) as broadly representative of Chinese cities in terms of size, location, and income (Krupnick et al., 2010). The US and Swedish respondents answered the survey online and were recruited through two large online panels. The 2009 survey yielded 1,221 usable responses in Sweden, 989 in the United States, and 1,264 in China. 
The second study was conducted as a web survey during February-April 2019 in all three countries. Before the main study, a pilot study was conducted in each country. The 2019 survey yielded 1,480 usable responses in Sweden, 1,436 in the United States, and 1,557 in China. ${ }^{4}$ The Swedish and US respondents were recruited from random samples of a representative panel from each population. ${ }^{5}$ The Chinese respondents were recruited from a panel that gave the opportunity to sample from the same four cities as in the 2009 survey. The 2019 panel in China had very few older respondents, creating differences between the two waves in China. To be able to compare the 2009 and 2019 waves, we decided to make a round of additional data collection in China in which we targeted older respondents. This data collection was done in December 2019. ${ }^{6}$

Participants in China were invited to take the survey in special rooms with laptops to collect data in 2009, whereas a web-based survey was used in 2019, so potential survey mode effects cannot strictly be excluded. The sense of observability and importance could presumably be stronger in the 2009 survey. In an extensive review, however, Lindhjem and Navrud (2011) conclude that the literature reports similar WTP estimates and no substantial differences between internet surveys and other survey modes. Our results are that the mean WTPs are substantially higher in 2019 than in 2009, which goes in the opposite direction from any survey mode effect.

\footnotetext{
${ }^{4}$ In total, we received 1,497 survey replies from Sweden, 1,461 from the United States, and 1,579 from China in 2019, but some had to be excluded from the study because of missing observations or extreme values of stated WTP (>\$220 per month). The 2009 survey had 1,229 responses in Sweden, 1,000 in the United States, and 1,448 in China.

${ }^{5}$ The Swedish respondents were representative in terms of age, gender, median income, and geography when compared with numbers at the national level (Statistics Sweden, 2018a, b, c), but university-educated respondents were overrepresented (Statistics Sweden, 2018d). The respondents from the US panel were representative in terms of age (CIA, 2018a), gender (US Census Bureau, 2018a), and geography (US Census Bureau, 2018b), but the share of university-educated respondents was too large compared with numbers at the national level (US Census Bureau, 2019). For China, the share of young people was overrepresented compared with national statistics (CIA, 2018b).

${ }^{6}$ An additional 405 interviews in total were conducted on December 2-10, 2019, in Nanning (109), Jiujiang (103), Chongqing (103), and Beijing (90) to complement the data with Chinese respondents age 55 and older. Interviewers visited parks, residential areas, shopping centers, and elderly homes. Representativeness was secured by conducting the interviews in different types of areas and having quotas for age and gender.
} 


\section{Results}

\section{A. Respondent Characteristics}

The econometric analysis (Tables 4-6) is based on 2,458 observations from the United States, 2,726 observations from Sweden, and 2,843 observations from China. Descriptive statistics for the demographic variables for the three countries in the two waves are shown in Appendix Table A1. Overall, most demographic variables are stable within countries across years, with a few exceptions. For both Sweden and the United States, the 2019 sample includes more university graduates. ${ }^{7}$ In addition, in Sweden, political preferences have changed from 2009 to 2019. In particular, support for the conservative and nationalistic right-wing party, the Sweden Democrats, tripled during this period (Valmyndigheten, 2019a, b). For the China sample, the main differences are that monthly income was substantially higher in the 2019 sample and that the average age was only around 40 years in 2019, whereas it was 54 years in 2009. Note also that the share of members of the Communist Party was relatively high in both waves, with a national average of around 6 percent, although this is likely higher in the urban population. In the analysis, we apply survey weights based on the correct level of educational attainment of the population in all three countries and in 2009 and 2019, respectively. For the Chinese sample, this also partly dealt with the overrepresentation of members of the Communist Party, since membership is more prevalent among those with a higher education. In addition, the main analysis comparing differences between the two waves controls for respondent characteristics.

\section{B. Attitudes toward Climate Change and Climate Policies}

Descriptive statistics of the most important attitudinal variables are presented in Table 2. The mean values in Table 2 are corrected to account for nonrepresentativeness of the samples with respect to educational attainment in all three countries using poststratification weights (see Appendix Table A4). Differences in means are tested using a Wald chi-squared test.

\footnotetext{
${ }^{7}$ For the Swedish and US samples, the larger shares of university graduates were mostly due to an overrepresentation of respondents with a university degree in the panels (see Appendix Table A2). For the Chinese sample, the overrepresentation of university graduates in our sample was lower in 2019 than in 2009 (see Appendix Table A3).
} 
Table 2. Attitudes toward Climate Change: Share of Respondents Agreeing with Each Statement

\begin{tabular}{|c|c|c|c|c|c|c|c|c|c|}
\hline \multirow[b]{2}{*}{ Statement } & \multicolumn{3}{|c|}{ United States } & \multicolumn{3}{|c|}{ Sweden } & \multicolumn{3}{|c|}{ China } \\
\hline & 2009 & 2019 & $p$-value ${ }^{a}$ & 2009 & 2019 & $p$-value ${ }^{a}$ & 2009 & 2019 & $p$-value ${ }^{a}$ \\
\hline Global temperature has not increased. & $24 \%$ & $16 \%$ & 0.000 & $6 \%$ & $7 \%$ & 0.446 & $5 \%$ & $3 \%$ & 0.011 \\
\hline Humans have affected the temperature. & $73 \%$ & $84 \%$ & 0.000 & $94 \%$ & $96 \%$ & 0.042 & $94 \%$ & $98 \%$ & 0.001 \\
\hline We cannot do anything to stop climate change. & $17 \%$ & $13 \%$ & 0.071 & $7 \%$ & $6 \%$ & 0.158 & $11 \%$ & $13 \%$ & 0.257 \\
\hline We can mitigate but not stop climate change. & $59 \%$ & $66 \%$ & 0.011 & $80 \%$ & $79 \%$ & 0.366 & $77 \%$ & $76 \%$ & 0.639 \\
\hline We can stop climate change. & $11 \%$ & $13 \%$ & 0.275 & $10 \%$ & $14 \%$ & 0.018 & $9 \%$ & $9 \%$ & 0.728 \\
\hline The climate is not changing. & $12 \%$ & $7 \%$ & 0.000 & $2 \%$ & $1 \%$ & 0.060 & $2 \%$ & $1 \%$ & 0.028 \\
\hline $\begin{array}{l}\text { Own country should reduce emissions, even if other } \\
\text { countries do not. }\end{array}$ & $68 \%$ & $79 \%$ & 0.000 & $81 \%$ & $73 \%$ & 0.000 & $77 \%$ & $89 \%$ & 0.000 \\
\hline $\begin{array}{l}\text { Own country should primarily use public funding to } \\
\text { reduce carbon emissions wherever it is cheapest, } \\
\text { even if it means in another country. }\end{array}$ & $16 \%$ & $26 \%$ & 0.00 & $43 \%$ & $43 \%$ & 0.966 & $34 \%$ & $41 \%$ & 0.005 \\
\hline $\begin{array}{l}\text { Own country should primarily use public funding to } \\
\text { reduce carbon emissions in own country. }\end{array}$ & $42 \%$ & $46 \%$ & 0.170 & $40 \%$ & $36 \%$ & 0.068 & $52 \%$ & $54 \%$ & 0.346 \\
\hline No opinion or other opinion. & $42 \%$ & $28 \%$ & 0.000 & $17 \%$ & $21 \%$ & 0.031 & $14 \%$ & $5 \%$ & 0.000 \\
\hline $\begin{array}{l}\text { We should deal with climate change primarily by } \\
\text { reducing emissions. }\end{array}$ & $59 \%$ & $67 \%$ & 0.003 & $85 \%$ & $83 \%$ & 0.259 & $80 \%$ & $78 \%$ & 0.267 \\
\hline $\begin{array}{l}\text { We should deal with climate change primarily by } \\
\text { adaptation. }\end{array}$ & $15 \%$ & $18 \%$ & 0.250 & $11 \%$ & $14 \%$ & 0.044 & $17 \%$ & $21 \%$ & 0.018 \\
\hline $\begin{array}{l}\text { Do nothing, because climate change is not a } \\
\text { problem. }\end{array}$ & $25 \%$ & $15 \%$ & 0.000 & $4 \%$ & $3 \%$ & 0.163 & $3 \%$ & $1 \%$ & 0.002 \\
\hline $\begin{array}{l}\text { The information in the survey regarding climate } \\
\text { change is trustworthy. }\end{array}$ & $49 \%$ & $61 \%$ & 0.000 & $81 \%$ & $79 \%$ & 0.388 & $86 \%$ & $92 \%$ & 0.000 \\
\hline $\begin{array}{l}\text { We should prioritize environmental improvements, } \\
\text { even if we lose jobs. }\end{array}$ & $40 \%$ & $60 \%$ & 0.000 & $61 \%$ & $55 \%$ & 0.013 & $75 \%$ & $82 \%$ & 0.001 \\
\hline No. of observations & 1000 & 1,458 & & 1,229 & 1,497 & & 1,264 & 1,579 & \\
\hline
\end{tabular}

Note: Survey weights based on educational attainment. See Appendix Table A4 for details.

${ }^{a} p$-value for Wald test of difference in means based on survey weights.

In Sweden, attitudes toward climate change were very similar in 2009 and 2019. Most Swedes acknowledge that human activity has caused rising temperatures to some degree and that we can and should mitigate climate change. However, there are a few statistically significant differences, albeit quite small, between 2009 and 2019. Most of these indicate that Swedish respondents are now somewhat less committed to certain climate change policies. For example, fewer respondents in 2019 thought that Sweden should prioritize the environment even if that means lost jobs (a decrease by 6 percentage points).

Several prominent and significant attitude changes occurred among the US respondents between 2009 and 2019, most of which were likely to make them more positive toward climate change policies. For instance, the share of people who acknowledge an increase in average global temperature rose by 8 percentage points, and the share who believe that humans have contributed to this rose by 11 percentage points. While the share of Swedish citizens who want their own country to reduce $\mathrm{CO}_{2}$ emissions, even if other countries do not, has significantly decreased during the past 10 years (81 versus 73 percent), the pattern is the opposite in the United States. In 2019, about 79 percent of US citizens in supported this position, while the corresponding number in 2009 was 68 percent. The largest change in the US samples was that 
in 2019, a significantly larger share (60 versus 40 percent) of US citizens were willing to prioritize the environment even at the expense of lost jobs.

The Chinese respondents also experienced changes in attitudes regarding climate change, most being more positive toward climate policies. For example, in 2019, 89 percent of the Chinese respondents thought that their own country should decrease $\mathrm{CO}_{2}$ emissions even if other countries do not, increasing from 77 percent in 2009. There was also stronger support for costefficient policies and for mitigation policies in 2019.

Our overarching conclusion is that the populations in these countries are converging in their attitudes. The Chinese and Americans are becoming more convinced of the necessity for climate change action and more committed to taking that action. Comparing across the countries, in general it seems that the Chinese to a greater extent believe that the climate is changing, followed by the Swedes and Americans. The Chinese also seemed more favorable in 2019 toward their country acting independently of what other countries do to reduce carbon emissions (89 percent), compared with the United States (78 percent) and Sweden (73 percent). In contrast, in 2009, Swedes were the most positive among the three countries about acting independently of other countries. However, the largest changes in climate-related attitudes have occurred in the United States. In the 2009 sample, 24 percent of US respondents did not believe that the global average temperature had increased, but in 2019, that share was 16 percent.

\section{Willingness to Pay for Reducing Greenhouse Gas Emissions}

Table 3 presents household monthly WTP to reduce $\mathrm{CO}_{2}$ emissions by 30, 60, and 85 percent. We use the number each respondent chose from a payment card matrix as an estimate of their maximum WTP. The WTPs are weighted to adjust for unrepresentativeness of educational attainment in all three countries (see Appendix Table A4 for the poststratification weights). Respondents' WTP is censored at the highest bid on the payment card. ${ }^{8}$ For the United States,

\footnotetext{
${ }^{8}$ We adjusted the WTP for individuals who stated a WTP outside the range of the payment card-that is, those who had a WTP larger than the highest bid of \$220 per month (in the US version) — and set it to \$220. This was because these individuals represent only a small proportion $(\approx 1 \%)$ of the population that potentially can have a great influence on the mean WTP. Mean WTP would be substantially lower if we instead exclude these responses, in particular for the United States. However, comparisons across time and between countries still reveal the same pattern, and we would reach the same conclusions as we do with the full set of observations.
} 
1.5 percent of the respondents exceeded this limit, and for China and Sweden, the corresponding fractions were 0.8 and 0.9 percent, respectively.

Table 3. Monthly Household WTP in in Purchasing Power Parity (PPP) and InflationAdjusted Dollars, Share of Zero WTP

\begin{tabular}{|c|c|c|c|c|c|c|c|c|c|}
\hline & \multicolumn{3}{|c|}{ United Sates } & \multicolumn{3}{|c|}{ Sweden } & \multicolumn{3}{|c|}{ China } \\
\hline & Mean & Share zero & Share inc. & Mean & Share zero & Share inc. & Mean & Share zero & Share inc. \\
\hline & \multicolumn{9}{|c|}{2019 wave } \\
\hline $30 \%$ reduction & $32(53)$ & 0.21 & 0.006 & $29(42)$ & 0.14 & 0.008 & $24(40)$ & 0.12 & 0.009 \\
\hline $60 \%$ reduction & $56(93)$ & 0.19 & 0.011 & $52(78)$ & 0.12 & 0.013 & 49 (78) & 0.10 & 0.018 \\
\hline \multirow[t]{2}{*}{$85 \%$ reduction } & $78(131)$ & 0.18 & 0.015 & $71(110)$ & 0.12 & 0.019 & 75 (118) & 0.09 & 0.027 \\
\hline & \multicolumn{9}{|c|}{2009 wave } \\
\hline $30 \%$ reduction & $20(42)$ & 0.29 & 0.005 & $23(35)$ & 0.10 & 0.006 & $6(9)$ & 0.21 & 0.003 \\
\hline $60 \%$ reduction & 32 (67) & 0.26 & 0.007 & $42(63)$ & 0.08 & 0.011 & $10(16)$ & 0.18 & 0.006 \\
\hline $85 \%$ reduction & $42(88)$ & 0.24 & 0.010 & $57(90)$ & 0.08 & 0.015 & $13(23)$ & 0.17 & 0.008 \\
\hline
\end{tabular}

Note: Survey weights based on educational attainment (see Appendix Table A4). Standard deviation in parentheses.

The WTP estimates increase with increasing $\mathrm{CO}_{2}$ reduction level in all three countries. In general, the WTP estimates are significantly higher for the 2019 wave for all three countries and quite similar in absolute values. The mean WTP for the 85 percent reduction levels in 2019 are strikingly similar, at \$78 in the United States, about \$71 in Sweden, and \$75 in China. For the 85 percent reduction level and from 2009 to 2019, China had the largest increase (477 percent), followed by the United States (86 percent). The increase in Sweden was relatively modest (25 percent). Moreover, only 9 percent of the respondents in China were not willing to pay anything to reduce emissions, compared with 12 percent in Sweden and 18 percent in the United States. This statistic has risen since 2009 by 4 percentage points (from 8 percent) in Sweden, but it has fallen by 6 percentage points (from 24 percent) in the United States and by 8 percentage points (from 17 percent) in China. Thus, the decrease in the fraction of zero WTP responses in the United States and China can partly explain the increase in their mean WTP, and it is another example of the convergence across countries we noted in the previous section. One possible explanation for the decrease in the share of zero WTPs in both China and the United States is the large and significant change in attitudes toward climate change and climate policies that we (and others) have documented.

Finally, we also estimate WTP as a share of mean income in each country. We find that Swedish respondents were willing to pay the largest share of their income in 2009, and the shares were very similar in the United States and China. In 2019, WTP measured as a share of income was quite similar across the countries for the 30 percent reduction level. However, at the 85 percent reduction level, the Chinese respondents stand out as willing to pay considerably 
more, the US respondents had the lowest value, and the Swedish respondents were intermediate.

\section{WTP for Reducing Greenhouse Gas Emissions and the Social Cost of Carbon}

We now compare our WTP estimates with the social cost of carbon (SCC). The SCC is the damage from emitting an additional ton of carbon dioxide and is used as a proxy for the value of reducing carbon emissions in the economics literature (see, e.g., Greenstone et al., 2013; Pizer et al., 2014; Drupp et al., 2018) as well as in policymaking, particularly in the United States (see, e.g., NASEM, 2017; OECD, 2018). Using public data on emissions in combination with population and household statistics, we perform a simple calculation of willingness to pay per ton of reduced carbon emissions based on our 30 percent reduction estimates as presented in Table 3. ${ }^{9}$ These values can then be compared with the range of SCC values usually referred to in the literature (see Rennert and Kingdon, 2019 for an overview of how to calculate the SCC). The WTP estimates for reducing a ton of $\mathrm{CO}_{2}$ derived from our estimates (for 2009 and 2019, respectively) are illustrated in Figure 1.

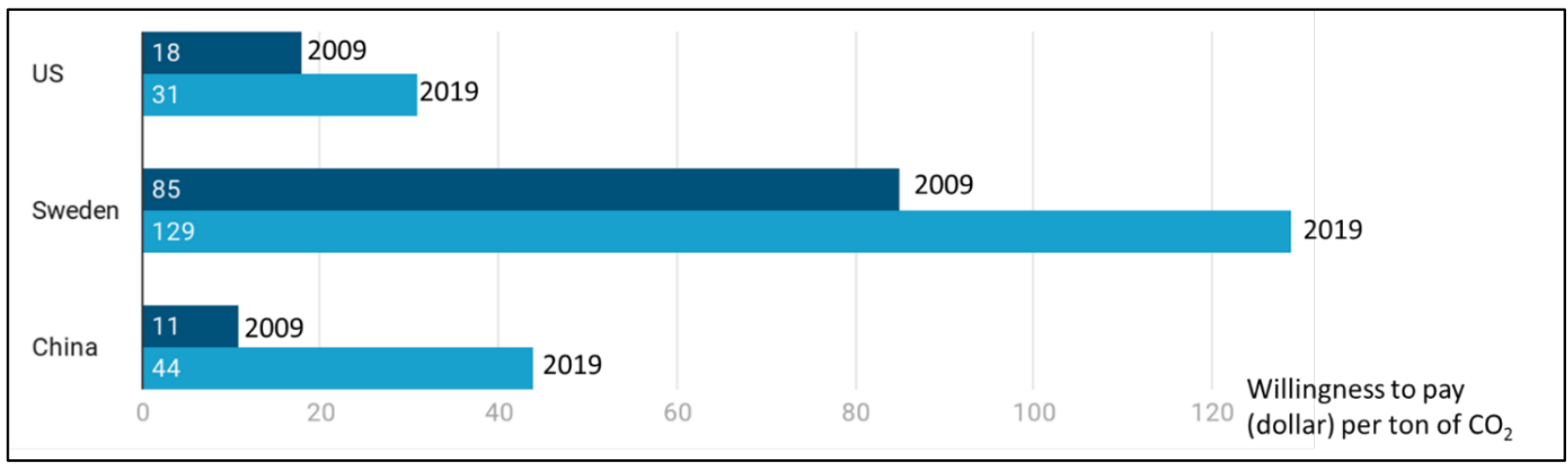

Figure 1. Willingness to Pay per Ton of $\mathrm{CO}_{2}$ by Country and Year (in dollars)

Even if our calculations are rudimentary, it is interesting to note that the WTP per ton of reduced $\mathrm{CO}_{2}$ for each of the three countries in 2019 compares, broadly speaking, with the conventional SCC estimates, even if Sweden is clearly in the higher range. On average, in 2019, Americans were willing to pay $\$ 31 /$ ton $\mathrm{CO}_{2}$, the Chinese $\$ 44 /$ ton $\mathrm{CO}_{2}$, and Swedes $\$ 129 /$ ton $\mathrm{CO}_{2}$. While the US value of $\$ 31 /$ ton $\mathrm{CO}_{2}$ is the lowest, it is still in the range of values of SCC

\footnotetext{
${ }^{9}$ See online supplementary material for details on the calculations and data sources used.
} 
discussed by the US Environmental Protection Agency (EPA). ${ }^{10}$ For Sweden, the $\$ 129 /$ ton $\mathrm{CO}_{2}$ corresponds almost exactly to the Swedish carbon tax, which is currently around \$126/ton $\mathrm{CO}_{2}{ }^{11}$ In 2009, the average WTP values were considerably lower, and hence the average values attributed to reducing a ton of $\mathrm{CO}_{2}$ have increased significantly in all three countries. These values have increased fourfold in China and by more than 50 percent in the United States and Sweden.

\section{Econometric Analysis}

To investigate the determinants of WTP and its change over the decade, we pool the data for the two waves and estimate a model for each of the three countries separately, using an interval regression model with survey weights to correct for overrepresentation in educational attainment. The interval model was chosen due to the payment card structure, which implies that we only know the ordered categories of WTP but not the exact value of the observation. A dummy variable is included to indicate the 2019 wave. The dependent variable is the interval for the stated WTP in PPP-adjusted dollars at 2018 prices. For brevity, we focus on WTP for reducing emissions by 30 percent compared with the business-as-usual scenario. ${ }^{12}$

\section{A. Changes in WTP and Determinants of WTP}

For each country, we estimate five models. The first, and simplest, model includes only a dummy variable for the 2019 wave as an explanatory variable (model 1). The model is then expanded with an increasing number of explanatory variables, adding socioeconomic characteristics (model 2), political attitudes (model 3), attitudes toward climate change and policy (model 4), and interaction terms with the dummy variable for the 2019 wave and all other explanatory variables (model 5). ${ }^{13}$

\footnotetext{
${ }^{10}$ EPA's central SCC estimate was $\$ 42 /$ ton in 2017 with a 3 percent discount rate (ranging from $\$ 12$ to $\$ 62$ for a 5 percent and 2.5 percent discount rate, respectively). https://19january2017snapshot.epa.gov/climatechange/social-cost-carbon_.html. The Trump administration ordered EPA to calculate a much lower domestic SCC that included damages from climate change only in the United States.

${ }^{11}$ The Swedish carbon tax was set to 1,180 SEK/ton $\mathrm{CO}_{2}$ in 2019, which at the exchange rate of 1 US\$ $=9.37$ SEK (https://www.forex.se/valuta/usd, accessed November 29, 2020) is 126 US\$/ton $\mathrm{CO}_{2}$.

${ }^{12}$ Results for 60 and 85 percent reductions for models 1 to 4 are presented in Appendix Tables A8-A10. Results are to a large extent unchanged with respect to statistical significance.

${ }^{13}$ Models 2-5 contain a set of location control variables. For the United States, we include four regional dummies, with the Southwest region as the reference region. For China, we include city dummy variables, with Beijing as the reference city. For Sweden, we include dummy variables based on the size of the city in which the respondent lives; in total, there are four groups, and the reference category is living in one of the three biggest cities in Sweden. Notably, bigger cities tend to have higher levels of air pollution, and some regions can be more vulnerable to climate change.
} 
Full results for models 1-5 for a 30 percent reduction are presented in Appendix Tables A5A7. In this section, we focus on the changes in WTP between the two survey rounds. Table 4 presents the estimates of the difference in WTP between the two survey waves for models 1-4 for the three countries.

Table 4. Estimated Difference between 2009 and 2019 Waves

\begin{tabular}{lccccc}
\hline Sample & Variable & $(1)$ & $(2)$ & $(3)$ & $(4)$ \\
\hline United States & 2019 wave & $9.11^{* *}$ & $6.85^{* *}$ & $7.46^{* * * *}$ & 2.43 \\
& & $(2.95)$ & $(2.70)$ & $(2.60)$ & $(2.49)$ \\
& Pseudo-R & 0.01 & 0.09 & 0.12 & 0.19 \\
\hline Sweden & 2019 wave & $4.44^{* * *}$ & $4.20^{* * *}$ & $5.13^{* * *}$ & $6.55^{* * *}$ \\
& & $(1.25)$ & $(1.23)$ & $(1.25)$ & $(1.24)$ \\
& Pseudo-R & 0.01 & 0.07 & 0.10 & 0.18 \\
\hline China & 2019 wave & $13.14^{* * *}$ & $9.02^{* * *}$ & $9.03^{* * *}$ & $8.31^{* * *}$ \\
& & $(0.91)$ & $(1.02)$ & $(1.02)$ & $(1.02)$ \\
& & 0.08 & 0.24 & 0.24 & 0.25 \\
\hline Location controls & & No & Yes & Yes & Yes \\
Socio-econ controls & & No & Yes & Yes & Yes \\
Political controls & & No & No & Yes & Yes \\
Attitude controls & & No & No & No & Yes
\end{tabular}

Note: Dependent variable is WTP in PPP and inflation-adjusted dollars for reducing emissions by 30\% compared with status quo. Standard errors in parentheses. The socioeconomic variables included in the regressions are capturing gender, age, education level, number of adults respectively children in a household, and income level. Variables capturing climate attitudes included opinions as to whether own country should decrease $\mathrm{CO}_{2}$ emissions regardless of what other countries would do, whether one is for a stricter environmental policy, whether one is for mitigation wherever it is cheapest, and whether one believes that global temperature has not increased. Number of observations are 2,726 for the Swedish sample, 2,458 in the US sample, and 2,843 in the Chinese sample. ${ }^{*} p<$ $0.1,{ }^{* *} p<0.05,{ }^{* * *} p<0.01$.

Model 1 implies that WTP is \$9.10 higher in 2019 than in 2009 in the US sample, and the corresponding numbers for Sweden and China are $\$ 4.40$ and $\$ 13.10$, respectively. ${ }^{14}$ Adding demographic and political preferences as controls does not significantly affect the difference in mean WTP between 2009 and 2019 in the US sample, but when adding attitudes toward climate change and policies, the 2019 dummy becomes statistically insignificant. Although the pseudo- $\mathrm{R}^{2}$ is low in all the models, there is a sizable increase in the pseudo- $\mathrm{R}^{2}$ when we add the attitudinal variables for the US sample in model 4. For the Swedish sample, the difference increases from $\$ 4.40$ to $\$ 5.10$ when adding demographic and political preference controls.

\footnotetext{
${ }^{14}$ These estimates are lower than what we saw with the raw data where we used the response on the payment card as the estimate of WTP.
} 
Moreover, when we add climate change attitudes, the difference between 2009 and 2019 actually increases to $\$ 6.60$. Similarly, as for the US sample, adding the attitudinal variables increases pseudo- $\mathrm{R}^{2}$ significantly in model 4. Finally, for China, the difference in WTP decreases to about $\$ 9.00$ if we add demographic and party membership controls and to $\$ 8.30$ if we add variables capturing attitudes toward climate change and policies. Further, the increase in pseudo- $\mathrm{R}^{2}$ comes mainly from adding demographic variables. For all three countries, a sizable fraction of the increase in WTP is unexplained even when adding a number of control variables.

In model 5, we include interaction terms between the dummy variable for the 2019 wave and all other independent variables. An interaction term reveals whether the increase in WTP from 2009 to 2019 is explained by any of the observable determinants. For example, if the interaction term between the time dummy and the female variable were positive and significant, that would mean that the increase in average WTP between 2009 and 2019 was partly driven by women increasing their WTP more than men. The full model results are presented in Appendix Tables A5-A7, while Table 5 reports only the interaction terms. 
Table 5. Marginal Effects of Interaction Terms for the United States, Sweden, and China in Model 5

\begin{tabular}{|c|c|c|c|}
\hline & US & Sweden & China \\
\hline \multirow[t]{2}{*}{2019 wave } & 34.68 & $-14.31^{*}$ & $30.94^{* * *}$ \\
\hline & $(22.62)$ & (8.67) & $(4.37)$ \\
\hline \multirow[t]{2}{*}{$2019 \times$ Female } & -6.10 & -2.82 & -1.89 \\
\hline & (4.34) & (2.37) & (1.72) \\
\hline \multirow[t]{2}{*}{$2019 \times$ Age } & -0.10 & 0.12 & $-0.71^{* * *}$ \\
\hline & $(0.13)$ & $(0.08)$ & $(0.07)$ \\
\hline \multirow[t]{2}{*}{$2019 \times$ Adults } & -3.56 & 1.84 & 0.72 \\
\hline & (3.25 & (1.93) & $(0.93)$ \\
\hline \multirow[t]{2}{*}{$2019 \times$ Children } & $-3.76^{*}$ & 0.62 & 1.47 \\
\hline & $(2.20)$ & $(1.44)$ & (1.73) \\
\hline \multirow[t]{2}{*}{$2019 \times$ High school } & $-24.83^{*}$ & 2.36 & 2.33 \\
\hline & $(14.80)$ & (3.74) & $(1.90)$ \\
\hline \multirow[t]{2}{*}{$2019 \times$ Post-high school } & $-27.72^{* *}$ & 2.96 & 1.83 \\
\hline & (13.13) & $(4.14)$ & $(2.85)$ \\
\hline \multirow[t]{2}{*}{$2019 \times$ University } & $-31.73^{* *}$ & 2.57 & 5.66 \\
\hline & $(14.75)$ & (4.18) & (3.64) \\
\hline \multirow[t]{2}{*}{$2019 \times$ Income } & $0.18^{* * *}$ & -0.001 & $-0.30^{* * *}$ \\
\hline & $(0.05)$ & $(0.08)$ & $(0.07)$ \\
\hline \multirow[t]{2}{*}{$2019 \times$ Democrat } & -5.56 & & \\
\hline & (7.03) & & \\
\hline \multirow[t]{2}{*}{$2019 \times$ Other } & -10.10 & & \\
\hline & (6.43) & & \\
\hline \multirow[t]{2}{*}{$2019 \times$ Independent } & -8.43 & & \\
\hline & $(5.52)$ & & \\
\hline \multirow[t]{2}{*}{$2019 \times$ Centrist } & & 2.22 & \\
\hline & & $(4.01)$ & \\
\hline \multirow{2}{*}{$2019 \times$ Left } & & $6.24^{* * *}$ & \\
\hline & & (3.02) & \\
\hline \multirow[t]{2}{*}{$2019 \times$ Other } & & 6.01 & \\
\hline & & (3.89) & \\
\hline \multirow[t]{2}{*}{$2019 \times$ Party member } & & 4.49 & $7.50^{* * *}$ \\
\hline & & (3.27) & $(2.40)$ \\
\hline \multirow[t]{2}{*}{$2019 \times$ Temp. not inc. } & 0.91 & 4.49 & 7.69 \\
\hline & (3.58) & $(3.27)$ & $(7.76)$ \\
\hline \multirow[t]{2}{*}{$2019 \times$ Own country } & $7.13^{*}$ & $5.33^{*}$ & 2.17 \\
\hline & $(4.30)$ & (2.73) & $(2.38)$ \\
\hline \multirow[t]{2}{*}{$2019 \times$ Mitigate cost-efficient } & -2.60 & 2.05 & 3.02 \\
\hline & $(6.30)$ & $(2.49)$ & $(1.89)$ \\
\hline \multirow[t]{2}{*}{$2019 \times$ Stricter env. pol. } & $8.32^{*}$ & 2.84 & $5.96^{* * *}$ \\
\hline & (5.05) & $(2.46)$ & $(2.26)$ \\
\hline
\end{tabular}

Note: Dependent variable is WTP in PPP and inflation-adjusted dollars for reducing emissions by $30 \%$ compared with status quo. Standard errors in parentheses. ${ }^{*} p<0.1,{ }^{* *} p<0.05,{ }^{* * *} p<0.01$. Democrat and independent refer to US party affiliations. In Sweden, "Centrist" consists of the Liberal and Center Parties, and "Left” consists of Left, Social Democrats, and Green Party. "Other" consists of other small parties. The reference group is rightwing parties, such as Republicans in the United States or the Moderate Party, Christian Democrats, and Sweden Democrats in Sweden. In China, the only variable is membership in the Communist Party.

There are several significant interaction terms, especially for the United States, where the interaction term for income is positive and statistically significant. This means that the increase in WTP between 2009 and 2019 is explained by higher-income groups increasing their WTP more than other income groups. Moreover, the interaction terms capturing educational levels are all large, negative, and significant, indicating that those with a low education level have increased their WTP relatively more between 2009 and 2019 than those with a higher education level. Moreover, those who believe that the United States should decrease their $\mathrm{CO}_{2}$ emissions 
regardless of what other countries would do, as well as those who are in favor of a stricter environmental policy, have increased their WTP relatively more than others have during the 10-year period. For Sweden, the increase in the average WTP from 2009 to 2019 was partly driven by the fact that left-wing voters increased their WTP relatively more than right-wing voters. For China, we find that older respondents and those with higher incomes have not increased their WTP as much as younger respondents and those with lower incomes. Moreover, members of the Communist Party and those who are for a stricter environmental policy have increased their WTP relatively more than others.

\section{B. Political Polarization and Climate Policy}

In this section, we explore the issue of political polarization and attitudes toward climate policy in Sweden and the United States. The word polarization is used to describe both a state (a connotation of a division of opinion) and a process whereby opinions become more divided. It is important to note that polarization can be measured in at least two ways: in absolute terms (the difference in WTPs) and in relative terms (the ratio of WTPs). Both measures of polarization can be used to understand the development of climate attitudes and WTP over time.

Relative polarization measures the ratio of WTP of one group compared with another group. Polarization in absolute terms measures the (dollar) difference in WTP of one group compared with another group. Since our focus will mainly be on whether polarization has increased between 2009 and 2019, it is important to note that absolute polarization may increase while the relative polarizations are either unchanged or decreased. For example, assume that WTP is initially twice as high for one group as for the other. Suppose both groups double their WTP at a later point in time. This would result in a doubled difference in absolute WTP but no change in relative WTP between the groups compared across time. Both measures are capturing the extent of polarization but in different units.

Absolute and percentage changes in WTP by (self-reported) political affiliation in the United States are illustrated in Figure 2 (summary statistics, including standard deviations and statistical significance, as well as comparisons of absolute and relative polarization can be found in Appendix Tables A11-A12). 


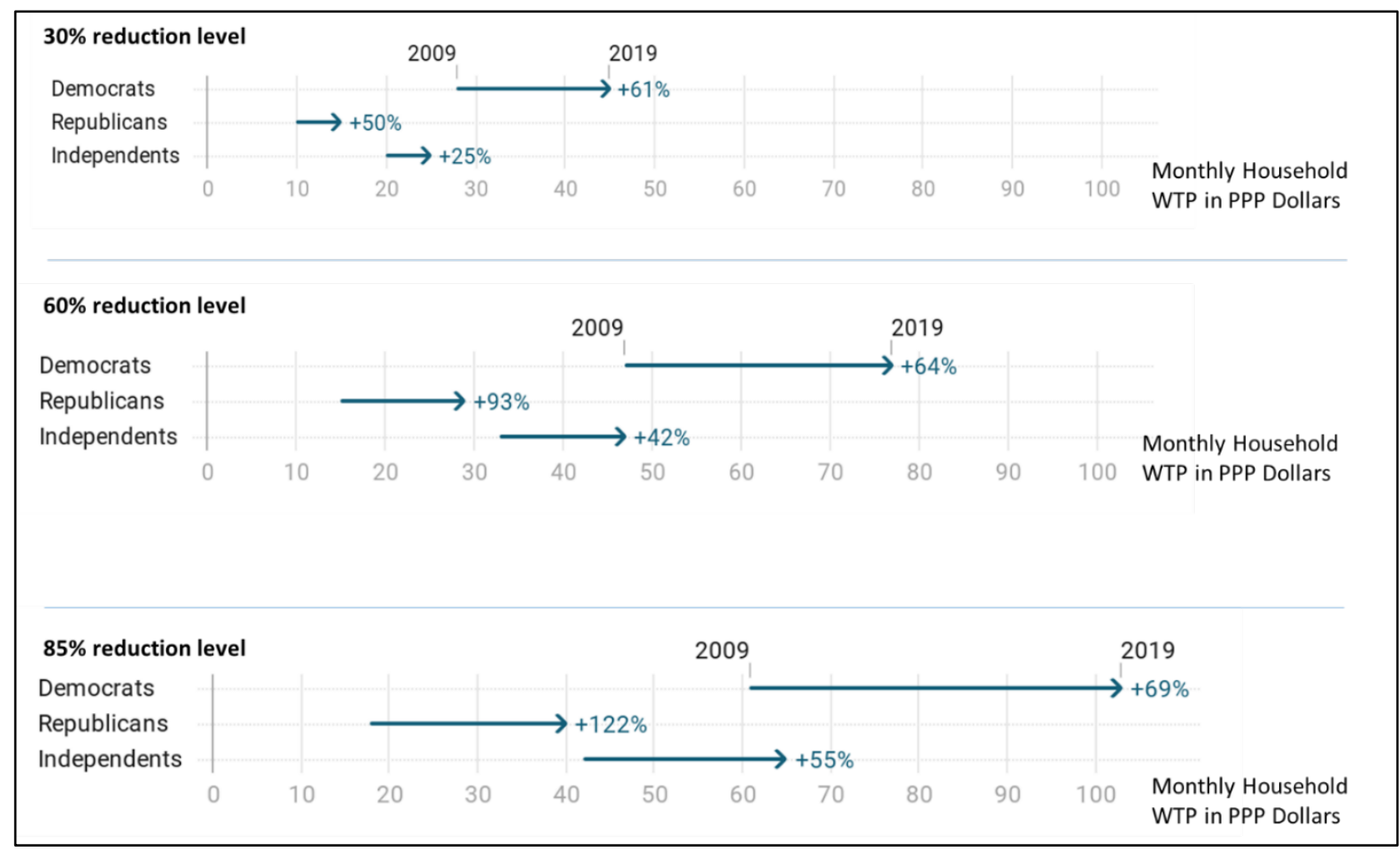

Figure 2. Absolute and Percentage Change in Mean Monthly Household WTP in PPP Dollars (survey weights) Comparing 2009 and 2019 for the United States

Note: The absolute changes are significant at the $1 \%$ to $5 \%$ significance levels for all the reduction levels for both political parties but not for independents at the $30 \%$ level (Wald test, p-value $=0.148$ ).

Given the polarized political discourse during the last decade, exemplified not least by the 2020 US presidential election campaign, one might expect to see increased polarization related to climate change policy between Republicans and Democrats. However, our overall results for the US sample show little support for an increase in polarization; rather, we find a general trend of increased WTP to reduce $\mathrm{CO}_{2}$ over the last decade among supporters irrespective of party. Comparing absolute changes in WTP, we find a statistically significant increase in polarization only for the 60 percent reduction level, and no statistically significant changes in relative polarization (for details and tests, see Appendix Table A12). Hence, even if there is a clear difference in climate policy opinion between Democrats and Republicans, and the increase in polarization measured as stated WTP between the parties for the last decade is sizable, the increase is not statistically significant. The same pattern holds for Democrats versus independents. The polarization between Republicans and independents in the last decade is negligible. 
However, the share of respondents not willing to pay anything for decreasing $\mathrm{CO}_{2}$ emissions (at the 85 percent reduction level) was significantly higher among Republicans than among both Democrats and independents in 2009 (35 percent versus 12 percent and 25 percent, respectively). While the share of zero WTP has significantly decreased during the past decade among both Democrats and independents, it is about the same among Republicans (see Appendix Table A13). ${ }^{15}$ Thus, a stable fraction of over one-third of the Republicans is not willing to pay anything for decreasing $\mathrm{CO}_{2}$ emissions. In 2009, this share among Republicans was three times larger than that of Democrats, and in 2019, it was more than sevenfold. Hence, there has been an increasing political polarization between Republicans and Democrats when it comes to the group of voters who are not willing to pay anything. Put another way, polarization has increased among Republican voters. Similarly, the gap between Republicans and independents not willing to pay anything widened during the past decade.

When it comes to climate attitudes, the share of both Democrats and Republicans who believe that humans have affected temperature increases had increased by about 10 percentage points in 2019 compared with 2009 (see Appendix Table A13). Almost all Democratic supporters and around two-thirds of Republican supporters now believe that humans have affected temperature increases. There was also a remarkable increase in support for prioritizing the environment among both Democrats and independents, while the increase in support among Republicans was relatively moderate. However, only among Democratic voters was there a considerable increase (from 80 to 96 percent) among those who think that their own country should decrease its carbon emissions even if other countries do not.

For Sweden, respondents are divided into three main groups: left-wing, centrist, and right-wing voters. ${ }^{16}$ Figure 3 illustrates the changes in WTP for the three different political groups (summary statistics, including standard deviations and statistical significance, as well as comparisons of absolute and relative polarization can be found in Appendix Tables A14-A16)

\footnotetext{
15 The decrease in the share of zero WTP at the 85 percent reduction level is statistically significant for both Democrats and independents at the 1 percent significance level, while the increase in the share of Republicans with zero WTP is not statistically significant (Wald test, $p$-value $=0.784$ ).

${ }^{16}$ In Sweden, “Centrist” consists of the Liberal and Center Parties, "Left” consists of the Left Party, Social Democrats, and the Green Party. Right-wing parties consist of the Moderate Party, Christian Democrats, and Sweden Democrats.
} 


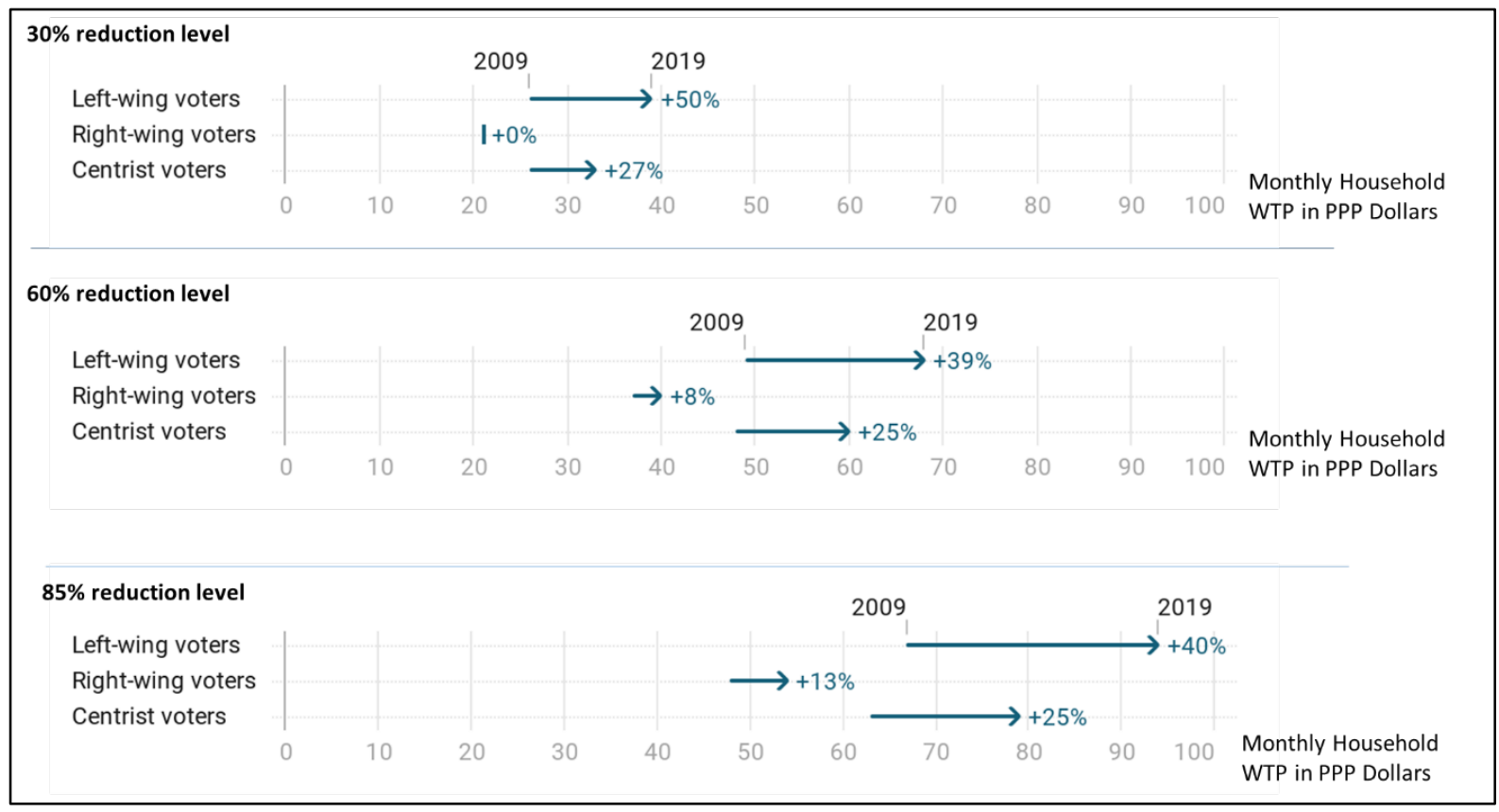

Figure 3. Absolute and Percentage Change in Monthly Household WTP in PPP Dollars (survey weights) Comparing 2009 and 2019 for Sweden

Note: According to the Wald test, the absolute changes are significant at all reduction levels for the left-wing voters ( $p$-value $=0.000$ for all the levels), and the change at the $30 \%$ reduction level is significant for the centrist voters $(p$-value $=0.083$ ). The changes are all statistically insignificant for the right-wing voters.

Notably, and unlike our findings for the United States, we find evidence of increased polarization in WTP in Sweden for both absolute and relative polarization metrics between left-wing and right-wing voters. However, there was no statistically significant change in polarization between the centrists and either of the other two groups (for details and tests, see Appendix Table A14). Similarly, as is the case with the US sample, the share of right-wing voters with a zero WTP is significantly larger than the corresponding shares of centrists and left-wing voters. Moreover, while the share of those with zero WTP remained stable from 2009 to 2019 among both centrists and left-wing voters, it significantly $(p$-value $=0.024)$ increased among the right-wing voters (from 12 to 18 percent). ${ }^{17}$

Regarding climate attitudes and beliefs about anthropogenic global warming, there was an increase (from 6 to 11 percent) in right-wing voters who think that we can stop climate change.

\footnotetext{
${ }^{17}$ As a robustness test, we reestimate the results in Appendix Table A15, this time excluding the populistic, rightwing conservative party Sweden Democrats from the right-wing parties (see Appendix Table A16). The difference between left- and right-wing voters largely remains, with the exception of the 60 percent reduction level. The share of zero WTP, however, did not significantly change between 2009 and 2019 when we exclude those who sympathize with the Sweden Democrats (Wald test, $p$-value $=0.258$ ). The share of Sweden Democrat voters has tripled in the country during the time period of our study (2009-19) (Valmyndigheten, 2019 a, b), and the party's support is rising.
} 
However, there was a considerable decrease (from 73 to 60 percent) among right-wing voters who think that their own country should decrease its carbon emissions even if other countries do not. In general, less support exists among Swedish right-wing voters for prioritizing the environment, and the share that shows support is considerably lower than among left-wing voters and centrists. Summing up, it is fair to say that political polarization has increased in relation to climate policy in Sweden during the last decade (see Appendix Table A17 for attitudinal results).

\section{Conclusions and Implications for Global Climate Policy}

The United States and China are the two largest carbon emitters in the world. While US per capita emissions are more than twice as high as in China, the emissions trends over the last decade are quite different. The United States experienced a decreasing emissions trend between 2000 and 2014, while emissions in China increased (World Bank, 2020). Since 2005, China has been emitting more in total than the United States and is the world's largest emitter. Notably, China alone has accounted for two-thirds of global emissions growth over the past decade (IEA, 2018). Europe accounts for less than 10 percent of total global emissions, and Sweden is an insignificant contributor, with per capita emissions that are approximately half of China’s and significantly lower than those of the United States.

Despite its marginal contribution to global carbon emissions, Sweden is known for its willingness to take a leading role in climate change mitigation and has adopted an ambitious climate target of zero net emissions by 2045. The United States, on the other hand, has withdrawn from the Paris Agreement under the Trump administration, although the incoming Biden administration has announced that the country will join again. The election outcome may well be one of the most significant factors in addressing global climate change during the coming decade. In addition, the United States has multiple ongoing state initiatives (e.g., California's initiatives for reducing climate change and the Regional Greenhouse Gas Initiative, a cooperative effort among 10 eastern states) and federal regulations (e.g., the Clean Air Act) in place to reduce greenhouse gases. China recently launched a large-scale national power sector emissions trading program to curb carbon emissions and is a leader in renewable energy (Ambrose, 2019), but the country relies heavily on coal, and new investments in coal are being planned at an alarming rate as part of the Belt and Road Initiative (Alvarez, 2019; Saha, 2019). Hence, these three countries reflect very different climate policy contexts, 
differences that may show up in citizens' attitudes toward climate policies and willingness to pay for climate mitigation.

Interestingly, our results show an increased willingness to pay for climate mitigation in all three countries. Notably, in 2019, the willingness to pay per ton of reduced $\mathrm{CO}_{2}$ compares closely to conventional measures of the social cost of carbon in China and the United States and to carbon taxes in Sweden. Ten years ago, Sweden stood out with a larger fraction of believers in anthropogenic climate change and a higher WTP for mitigation. Over the last decade, there have been greater increases in both of these measures in China and the United States, so today the national averages are much more similar. Now China stands out with a higher WTP as a share of income. When interpreting these figures, we need to bear in mind the dramatic changes in these countries over the time period studied. The increased WTP in China should be considered against a background of rapidly rising income, even more rapidly escalating emissions, and a strong increase in stated commitment among political leaders to address climate change. The Swedish numbers may also be seen in the light of a country that has been rather ambitious in its climate efforts but, with a relatively stagnant economy, is now trying to stimulate its economy and coordinate mitigation efforts with other countries in the EU, including countries that are more skeptical toward more stringent climate policies.

What does all this imply for the future of climate policy? A key reason for political inaction could be that public demand for more stringent policies is weak. However, we do not find support for such arguments. Instead, we find that for all three countries, the average WTP per ton of carbon emissions reduced is within the range of the social cost of carbon values usually referred to in the literature. In Sweden, WTP per ton of carbon emissions reduced is comparable to the Swedish carbon tax (approximately \$126/ton), and in the United States, it is below but roughly on par with EPA’s central estimates of the social cost of carbon in 2017 (\$42/ton).

On the other hand, within countries, these averages conceal considerable preference divergence, most importantly relating to political affiliation. We find a clear left-right difference in WTP in both the United States and Sweden. In the United States, the average WTP of self-identified Republicans is significantly lower than that of others, especially Democrats. At the same time, this difference in preferences was already present in 2009, and we find little evidence of sizable increases in polarization across Democrats and Republicans when looking at the whole sample. In Sweden, however, which was more homogeneous earlier, 
there is stronger evidence of increased polarization in both preferences and attitudes toward climate policy. While WTP for climate change policy among right-wing voters has increased, it has increased to a significantly lesser degree than among left-wing and centrist voters. Moreover, in both the United States and Sweden, the share of respondents with zero WTP is significantly higher among Republicans and right-wing party voters than among any other voters, and that gap has increased during the past decade. Hence, while we see convergent tendencies across countries, there is some evidence of increased divergence within countries.

Returning to our initial question whether the increasing warning signs over the last decade that the earth is warming are matched by citizens' demand for stronger policy action, the answer is affirmative and positive for those who have hoped that electorates will demand more stringent climate policies from their leaders. This greater support for climate action could influence future domestic and global policies. However, a consequence of political polarization might be that large groups of citizens are unhappy with their country's climate politics. If so, political polarization could shift the focus from climate to ideology, and political decisions about climate policies could become more difficult to reach both nationally and globally. 


\section{References}

Alvarez, C. F. 2019. "Commentary: Fading Fast in the US and Europe, Coal Still Reigns in Asia.” December 12. International Energy Agency.

https://www.iea.org/commentaries/fading-fast-in-the-us-and-europe-coal-still-reignsin-asia.

Ambrose, J. 2019. “China’s Appetite for Coal Power Returns despite Climate Pledge.” Guardian, November 20. https://www.theguardian.com/world/2019/nov/20/chinaappetite-for-coal-power-stations-returns-despite-climate-pledge-capacity.

Carlsson, F., M. Kataria, A. Krupnick, E. Lampi, Å. Löfgren, P. Qin, S. Chung, and T. Sterner. 2012. "Paying for Mitigation: A Multiple Country Study.” Land Economics 88 (2): 326-40. https://doi.org/10.3368/le.88.2.326.

Carlsson, F., M. Kataria, A. Krupnick, E. Lampi, Å. Löfgren, P. Qin, and T. Sterner. 2013. “A Fair Share: Burden-Sharing Preferences in the United States and China.” Resource and Energy Economics 35 (1): 1-17.

CIA (Central Intelligence Agency). 2018a. The World Factbook, United States. https://www.cia.gov/library/publications/the-world-factbook/geos/us.html.

— . 2018b. The World Factbook, China. https://www.cia.gov/library/publications/theworld-factbook/geos/ch.html.

Drupp, M. A., M. C. Freeman, B. Groom, and F. Nesje. 2018. "Discounting Disentangled.” American Economic Journal: Economic Policy 10 (4): 109-34.

Greenstone, M., E. Kopits, and A. Wolverton. 2013. “Developing a Social Cost of Carbon for US Regulatory Analysis: A Methodology and Interpretation.” Review of Environmental Economics and Policy 7 (1): 23-46.

Guber, D. L. 2013. “A Cooling Climate for Change? Party Polarization and the Politics of Global Warming.” American Behavioral Scientist 57 (1), 93-115.

Hoffman, A. J. 2011. “The Growing Climate Divide.” Nature Climate Change 1 (4): 195-96.

Hornsey, M. J., E. A. Harris, P. G. Bain, and K. S. Fielding. 2016. "Meta-Analyses of the Determinants and Outcomes of Belief in Climate Change.” Nature Climate Change 6 (6): 622-26.

Hornsey, M. J., E. A. Harris, and K. S. Fielding. 2018. "Relationships among Conspiratorial Beliefs, Conservatism and Climate Scepticism across Nations.” Nature Climate Change 8 (7): 614-20. 
IEA (International Energy Agency). 2018. $\mathrm{CO}_{2}$ Emissions from Fuel Combustion 2018. Paris: IEA.

Jamelske, E., J. Boulter, W. Jang, J. Barrett, L. Miller, and W. L. Han. 2015. “Examining Differences in Public Opinion on Climate Change between College Students in China and the USA.” Journal of Environmental Studies and Sciences 5 (2): 87-98. https://doi.org/10.1007/s13412-015-0229-9.

Johnston, R. J., K. J. Boyle, W. Adamowicz, J. Bennett, R. Brouwer, T. A. Cameron, @. M. Hanemann, et al. 2017. “Contemporary Guidance for Stated Preference Studies.” Journal of the Association of Environmental and Resource Economists 4 (2): 319405.

Keohane, R. O., and D. G. Victor. 2011. “The Regime Complex for Climate Change.” Perspectives on Politics 9 (1): 7-23.

Kousser, T., and B. Tranter. 2018. “The Influence of Political Leaders on Climate Change Attitudes.” Global Environmental Change 50:100-109.

Krinsky, I., and L. Robb. “On Approximating the Statistical Properties of Elasticities.” Review of Economics and Statistics 68:715-19.

Krupnick, A., S. Hoffman, and P. Qin. 2010. “The Willingness to Pay for Mortality Risk Reductions in China.” Working paper. Washington, DC: Resources for the Future.

Lindhjem, H., and S. Navrud. 2011. "Using Internet in Stated Preference Surveys: A Review and Comparison of Survey Modes.” International Review of Environmental and Resource Economics 5 (4): 309-51.

Malka, A., J. A. Krosnick, and G. Langer. 2009. "The Association of Knowledge with Concern about Global Warming: Trusted Information Sources Shape Public Thinking.” Risk Analysis 29 (5): 633-47.

Martinsson, J., and M. Weissenbilder. 2019 ’Polariserade problembeskrivningar?” i Andersson m.fl. (red) Storm och stiltje. GU: SOM-institutet.

Meginnis, K., M. Burton, R. Chan, and D. Rigby. 2018. "Strategic Bias in Discrete Choice Experiments.” Journal of Environmental Economics and Management 102163. https://doi.org/10.1016/j.jeem.2018.08.010.

Muis, J., and T. Immerzeel. 2017. “Causes and Consequences of the Rise of Populist Radical Right Parties and Movements in Europe.” Current Sociology 65 (6): 909-30. https://doi.org/10.1177/0011392117717294. 
NASEM (National Academies of Sciences, Engineering, and Medicine). 2017. Valuing Climate Damages: Updating Estimation of the Social Cost of Carbon Dioxide. Washington, DC: National Academies Press. https://doi.org/10.17226/24651.

OECD (Organisation for Economic Co-operation and Development). 2018. "Current Use of Cost-Benefit Analysis.” Chap. 14 in Cost-Benefit Analysis and the Environment: Further Developments and Policy Use. Paris: OECD Publishing. https://doi.org/10.1787/9789264085169-en.

Pizer, W., M. Adler, J. Aldy, D. Anthoff, M. Cropper, K. Gillingham, M. Greenstone, et al. 2014. "Using and Improving the Social Cost of Carbon.” Science 346 (6214): 118990.

PPRG (Political Psychology Research Group). 2018. “American Public Opinion on Global Warming.” Stanford University. https://climatepublicopinion.stanford.edu/.

Rennert, K., and C. Kingdon. 2019. "Social Cost of Carbon 101: A Review of the Social Cost of Carbon, from a Basic Definition to the History of Its Use in Policy Analysis.” Washington, DC: Resources for the Future.

Saha, S. 2019. “China’s Belt and Road Plan Is Destroying the World.” National Interest, August 18. https://nationalinterest.org/feature/chinas-belt-and-road-plan-destroyingworld-74166.

Schwirplies, C. 2018. “Citizens’ Acceptance of Climate Change Adaptation and Mitigation: A Survey in China, Germany, and the U.S.” Ecological Economics 145:308-22. https://doi.org/10.1016/J.ECOLECON.2017.11.003.

Statistics Sweden. 2018a. "Population by Age and Sex: Year 1860-2018.” http://www.statistikdatabasen.scb.se/pxweb/en/ssd/START_BE_BE0101_BE0101

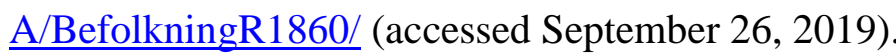
. 2018b. "Median Salaries in Sweden.” [In Swedish.] https://www.scb.se/hittastatistik/sverige-i-siffror/utbildning-jobb-och-pengar/medianloner-i-sverige/ (accessed September 25, 2019).

. 2018c. "Population by Region, Marital Status, Age and Sex: Year 1968-2018.” http://www.statistikdatabasen.scb.se/pxweb/en/ssd/START_BE_BE0101_BE0101 A/BefolkningNy/table/tableViewLayout1/ (accessed September 26, 2019). . 2018d. “Education Level in Sweden.” [In Swedish.] https://www.scb.se/hittastatistik/sverige-i-siffror/utbildning-jobb-och-pengar/utbildningsnivan-isverige/?showRelatedArticles=False\&showRelatedFacts=True (accessed September 25, 2019). 
US Census Bureau. 2018a. "Quick Facts: Age and Sex.”

https://www.census.gov/quickfacts/fact/table/U.S./LFE046217 (accessed September 26, 2019).

—. 2018b. "Table 1. Annual Estimates of the Resident Population for the United States, Regions, States, and Puerto Rico: April 1, 2010 to July 1, 2018.” NST-EST2018-01. https://www.census.gov/newsroom/press-kits/2018/pop-estimates-national-state.html (accessed September 26, 2019).

—. 2019. "Table 1. Educational Attainment of the Population 18 Years and Over, by Age, Sex, Race, and Hispanic Origin: 2018; All Races.” https://www.census.gov/data/tables/2018/demo/education-attainment/cps-detailedtables.html (accessed September 26, 2019).

Valmyndigheten [Swedish Election Authority]. 2019a. “Election Results 2010.” [In

Swedish.] https://val.se/valresultat/riksdag-landsting-och-

kommun/2010/valresultat.html (accessed October 21, 2019).

_ . 2019b. “Election Results 2018.” [In Swedish.]

https://www.val.se/servicelankar/other-languages/english-engelska/election-results2018.html (accessed October 21, 2019).

Vossler, C. A., M. Doyon, and D. Rondeau. 2012. “Truth in Consequentiality: Theory and Field Evidence on Discrete Choice Experiments.” American Economic Journal: Microeconomics 4(4): 145-71.

Welsh, M. P., and G. L. Poe. 1998. "Elicitation Effects in Contingent Valuation: Comparisons to a Multiple Bounded Discrete Choice Approach.” Journal of Environmental Economics and Management 36(2): 170-85.

Westfall, J., L. Van Boven, J. R. Chambers, and C. M. Judd. 2015. “Perceiving Political Polarization in the United States: Party Identity Strength and Attitude Extremity Exacerbate the Perceived Partisan Divide.” Perspectives on Psychological Science 10 (2): 145-58. https://doi.org/10.1177/1745691615569849.

Winden, M., E. Jamelske, and E. Tvinnereim. 2018. “A Contingent Valuation Study Comparing Citizen's Willingness-to-Pay for Climate Change Mitigation in China and the United States.” Environmental Economics and Policy Studies 20 (2): 451-75. https://doi.org/10.1007/s10018-017-0202-9.

World Bank. 2019. “State and Trends of Carbon Pricing 2019.” Washington, DC: World Bank Group. https://openknowledge.worldbank.org/handle/10986/31755 (accessed April 28, 2020). 
. 2020. “World Development Indicators.” Washington, DC: World Bank Group.

https://datacatalog.worldbank.org/dataset/world-development-indicators (accessed February 14, 2020).

Zawojska, E., A. Bartczak, and M. Czajkowski. 2019. "Disentangling the Effects of Policy and Payment Consequentiality and Risk Attitudes on Stated Preferences.” Journal of Environmental Economics and Management 93:63-84.

Ziegler, A. 2017. "Political Orientation, Environmental Values, and Climate Change Beliefs and Attitudes: An Empirical Cross Country Analysis.” Energy Economics 63:144-53. https://doi.org/10.1016/J.ENECO.2017.01.022. 


\section{Appendix A}

Table A1. Descriptive Statistics of Demographic Variables, Mean Values

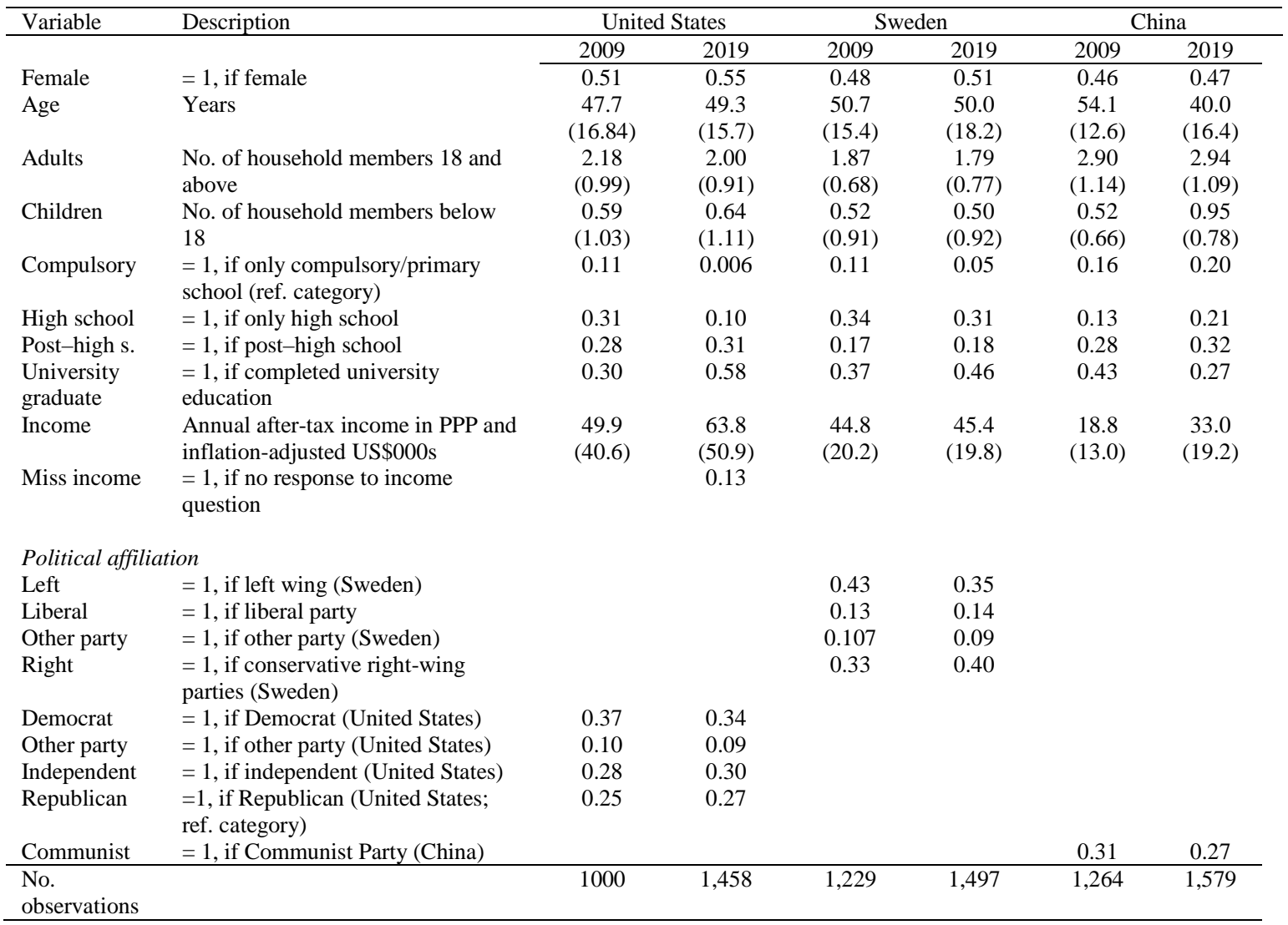

Note: Standard deviations in brackets. 
Table A2. Mean Values Sample Statistics

\begin{tabular}{|c|c|c|c|c|c|c|c|}
\hline \multirow[t]{2}{*}{ Variable } & \multirow[t]{2}{*}{ Description } & \multicolumn{2}{|c|}{ United States } & \multicolumn{2}{|c|}{ Sweden } & \multicolumn{2}{|c|}{ China } \\
\hline & & 2009 & 2019 & 2009 & 2019 & 2009 & 2019 \\
\hline Compulsory & $=1$, if only compulsory/primary school & 0.11 & 0.005 & 0.11 & 0.05 & 0.16 & 0.20 \\
\hline High school & $=1$, if only high school & 0.31 & 0.10 & 0.34 & 0.31 & 0.14 & 0.21 \\
\hline Post-high school & $=1$, if post-high school & 0.28 & 0.31 & 0.18 & 0.18 & 0.28 & 0.32 \\
\hline University & $=1$, if completed university education & 0.30 & 0.58 & 0.37 & 0.45 & 0.40 & 0.26 \\
\hline
\end{tabular}

Table A3. Population Statistics

\begin{tabular}{|c|c|c|c|c|c|c|c|}
\hline \multirow[t]{2}{*}{ Variable } & \multirow[t]{2}{*}{ Description } & \multicolumn{2}{|c|}{ United States } & \multicolumn{2}{|c|}{ Sweden } & \multicolumn{2}{|c|}{ China } \\
\hline & & 2009 & 2019 & 2009 & 2019 & 2009 & 2019 \\
\hline Compulsory & $=1$, if only compulsory/primary school & 0.31 & 0.38 & 0.20 & 0.18 & 0.27 & 0.24 \\
\hline High school & $=1$, if only high school & 0.24 & 0.23 & 0.47 & 0.44 & 0.39 & 0.37 \\
\hline Post-high school & $=1$, if post-high school & 0.31 & 0.29 & 0.18 & 0.15 & 0.18 & 0.19 \\
\hline University & $=1$, if completed university education & 0.14 & 0.12 & 0.19 & 0.23 & 0.16 & 0.20 \\
\hline
\end{tabular}

Table A4. Poststratification Weights for Countries

\begin{tabular}{|c|c|c|c|c|c|c|c|}
\hline \multirow[t]{2}{*}{ Variable } & \multirow[t]{2}{*}{ Description } & \multicolumn{2}{|c|}{ United States } & \multicolumn{2}{|c|}{ Sweden } & \multicolumn{2}{|c|}{ China } \\
\hline & & 2009 & 2019 & 2009 & 2019 & 2009 & 2019 \\
\hline Compulsory & $=1$, if only compulsory/primary school & 2.81 & 7.60 & 1.81 & 3.6 & 1.69 & 1.2 \\
\hline High school & $=1$, if only high school & 0.77 & 2.30 & 1.38 & 1.42 & 2.79 & 1.76 \\
\hline Post-high school & $=1$, if post-high school & 1.10 & 0.93 & 1 & 0.83 & 0.64 & 0.59 \\
\hline University & $=1$, if completed university education & 0.47 & 0.21 & 0.51 & 0.51 & 0.4 & 0.77 \\
\hline
\end{tabular}

Note: Poststratification weight = population mean / sample mean. 
Table A5. United States: Marginal Effects from Interval Regression Model

\begin{tabular}{|c|c|c|c|c|c|}
\hline & $(1)$ & $(2)$ & (3) & (4) & (5) \\
\hline \multirow[t]{2}{*}{2019 sample } & $9.11^{* *}$ & $6.85^{* *}$ & $7.45^{* * *}$ & 2.43 & 34.68 \\
\hline & $(2.95)$ & (2.69) & $(2.60)$ & (2.49) & (22.62) \\
\hline \multirow{2}{*}{ Female } & & -4.38 & $-5.32^{*}$ & $-5.39^{* *}$ & -1.97 \\
\hline & & (3.10) & (3.06) & $(2.68)$ & $(2.07)$ \\
\hline \multirow[t]{2}{*}{ Age } & & -0.09 & -0.08 & -0.02 & 0.05 \\
\hline & & $(0.07)$ & $(0.07)$ & $(0.07)$ & $(0.07)$ \\
\hline \multirow[t]{2}{*}{ No. of adults } & & 0.57 & 0.19 & 0.63 & 2.72 \\
\hline & & (1.89) & (1.89) & (1.68) & $(2.47)$ \\
\hline \multirow[t]{2}{*}{ No. of children } & & $-3.13^{* *}$ & $-2.89^{* *}$ & $-2.07^{*}$ & 0.03 \\
\hline & & (1.19) & $(1.16)$ & (1.15) & (1.06) \\
\hline \multirow[t]{2}{*}{ High school } & & $-23.15^{* *}$ & $-21.09^{* *}$ & $-21.07^{* *}$ & $-7.40^{*}$ \\
\hline & & $(10.37)$ & $(10.29)$ & (9.65) & (3.91) \\
\hline \multirow[t]{2}{*}{ Post-high school } & & $-21.78^{* * *}$ & $-20.26^{* *}$ & $-20.61^{* *}$ & -3.72 \\
\hline & & (9.87) & (9.87) & $(9.25)$ & $(4.06)$ \\
\hline \multirow[t]{2}{*}{ University graduate } & & -17.27 & -16.50 & $-18.66^{*}$ & 1.68 \\
\hline & & $(11.56)$ & $(11.40)$ & (10.83) & $(4.47)$ \\
\hline \multirow[t]{2}{*}{ Income } & & $0.15^{* * *}$ & $0.15^{* * *}$ & $0.14^{* * *}$ & 0.03 \\
\hline & & $(0.03)$ & $(0.03)$ & $(0.03)$ & $(0.03)$ \\
\hline \multirow[t]{2}{*}{ No response income } & & 17.12 & 19.27 & 17.19 & $20.79^{*}$ \\
\hline & & $(13.54)$ & $(13.70)$ & (11.98) & (11.04) \\
\hline \multirow[t]{2}{*}{ Democrat } & & & $16.35^{* * *}$ & 5.79 & $9.28^{* * * *}$ \\
\hline & & & (3.96) & $(4.34)$ & $(2.54)$ \\
\hline \multirow[t]{2}{*}{ Other party } & & & -0.22 & -1.61 & 5.36 \\
\hline & & & $(4.55)$ & $(4.09)$ & $(4.01)$ \\
\hline \multirow[t]{2}{*}{ Independent } & & & 4.06 & 0.23 & $5.68^{* *}$ \\
\hline & & & (3.86) & $(3.75)$ & $(2.50)$ \\
\hline Temp. has not increased & & & & $-4.74^{* *}$ & $-4.56^{*}$ \\
\hline & & & & $(1.61)$ & $(2.35)$ \\
\hline Own country should lead & & & & $4.99^{* *}$ & 0.81 \\
\hline & & & & $(2.07)$ & $(2.36)$ \\
\hline Mitigate cost-efficient & & & & 5.04 & $5.58^{*}$ \\
\hline & & & & $(4.20)$ & $(3.28)$ \\
\hline Supp. strict. env. pol. & & & & $19.14^{* * *}$ & $14.49^{* * *}$ \\
\hline & & & & (2.68) & (2.66) \\
\hline $2019 \times$ Female & & & & & -6.10 \\
\hline & & & & & $(4.35)$ \\
\hline $2019 \times$ Age & & & & & -0.10 \\
\hline & & & & & $(0.13)$ \\
\hline $2019 \times$ Adults & & & & & -3.56 \\
\hline & & & & & $(3.25)$ \\
\hline $2019 \times$ Children & & & & & $-3.76^{*}$ \\
\hline & & & & & $(2.20)$ \\
\hline $2019 \times$ High s. & & & & & $-24.83^{*}$ \\
\hline & & & & & $(14.80)$ \\
\hline $2019 \times$ Post-hi. & & & & & $-27.72^{* *}$ \\
\hline & & & & & (13.13) \\
\hline $2019 \times$ Univ & & & & & $-31.73^{* *}$ \\
\hline & & & & & (14.75) \\
\hline $2019 \times$ Income & & & & & $0.18^{* * *}$ \\
\hline & & & & & $(0.05)$ \\
\hline $2019 \times$ Demo & & & & & -5.56 \\
\hline & & & & & $(7.03)$ \\
\hline $2019 \times$ Other & & & & & -10.10 \\
\hline & & & & & $(6.43)$ \\
\hline $2019 \times$ Inde & & & & & -8.43 \\
\hline & & & & & $(5.52)$ \\
\hline $2019 \times$ Temp. not inc. & & & & & 0.91 \\
\hline & & & & & (3.58) \\
\hline $2019 \times$ Own country & & & & & $7.13^{*}$ \\
\hline & & & & & $(4.30)$ \\
\hline $2019 \times$ Mit. cost-efficient & & & & & -2.60 \\
\hline & & & & & $(6.30)$ \\
\hline $2019 \times$ Stricter env. pol. & & & & & $8.32^{*}$ \\
\hline & & & & & $(5.05)$ \\
\hline Locational controls & No & Yes & Yes & Yes & Yes \\
\hline No. observations & 2,458 & 2,458 & 2,458 & 2,458 & 2,458 \\
\hline
\end{tabular}

Note: Dependent variable is WTP for $30 \%$ reduction of emissions. Standard errors in parentheses. ${ }^{*} p<0.1,{ }^{* *} p$ $<0.05,{ }^{* * *} p<0.01$. 
Table A6. Sweden: Marginal Effects from Interval Regression Model

\begin{tabular}{|c|c|c|c|c|c|}
\hline & (1) & (2) & (3) & (4) & (5) \\
\hline 2019 sample & $\begin{array}{l}4.44^{* * *} \\
(1.25)\end{array}$ & $\begin{array}{l}4.20^{* * *} \\
(1.23)\end{array}$ & $\begin{array}{c}5.13^{* * *} \\
(1.25)\end{array}$ & $\begin{array}{l}6.55^{* * *} \\
(1.24)\end{array}$ & $\begin{array}{c}-14.31^{*} \\
(8.67)\end{array}$ \\
\hline Female & & $\begin{array}{c}-3.29^{* * * *} \\
(1.24)\end{array}$ & $\begin{array}{c}-3.64^{* * *} \\
(1.23)\end{array}$ & $\begin{array}{c}-3.71^{* * *} \\
(1.22)\end{array}$ & $\begin{array}{l}-2.13 \\
(1.61)\end{array}$ \\
\hline Age & & $\begin{array}{c}-0.12^{* * *} \\
(0.04)\end{array}$ & $\begin{array}{c}-0.12^{* * *} \\
(0.04)\end{array}$ & $\begin{array}{c}-0.12^{* * * *} \\
(0.04)\end{array}$ & $\begin{array}{c}-0.20^{* * *} \\
(0.07)\end{array}$ \\
\hline No. of adults & & $\begin{array}{l}-0.35 \\
(1.04)\end{array}$ & $\begin{array}{l}-0.19 \\
(1.00)\end{array}$ & $\begin{array}{c}0.30 \\
(0.93)\end{array}$ & $\begin{array}{l}-0.82 \\
(1.47)\end{array}$ \\
\hline No. of children & & $\begin{array}{l}-1.13 \\
(0.75)\end{array}$ & $\begin{array}{l}-1.08 \\
(0.75)\end{array}$ & $\begin{array}{l}-0.82 \\
(0.72)\end{array}$ & $\begin{array}{l}-1.20 \\
(1.06)\end{array}$ \\
\hline High school & & $\begin{array}{l}4.71^{* *} \\
(1.89)\end{array}$ & $\begin{array}{l}5.36^{* * *} \\
(1.90)\end{array}$ & $\begin{array}{l}4.59^{* * *} \\
(1.84)\end{array}$ & $\begin{array}{l}3.20 \\
(2.39)\end{array}$ \\
\hline Post-high school & & $\begin{array}{l}3.92^{*} \\
(2.13)\end{array}$ & $\begin{array}{l}4.72^{* *} \\
(2.14)\end{array}$ & $\begin{array}{l}3.56^{*} \\
(2.08)\end{array}$ & $\begin{array}{l}1.71 \\
(2.62)\end{array}$ \\
\hline University graduate & & $\begin{array}{c}14.12^{* * * *} \\
(2.24)\end{array}$ & $\begin{array}{c}14.65^{* * * *} \\
(2.25)\end{array}$ & $\begin{array}{c}12.03^{* * *} \\
(2.18)\end{array}$ & $\begin{array}{c}10.37^{* * * *} \\
(2.88)\end{array}$ \\
\hline Income & & $\begin{array}{l}0.30^{* * * *} \\
(0.04)\end{array}$ & $\begin{array}{l}0.30^{* * *} \\
(0.04)\end{array}$ & $\begin{array}{l}0.29^{* * * *} \\
(0.04)\end{array}$ & $\begin{array}{l}0.29^{* * * *} \\
(0.05)\end{array}$ \\
\hline Centrist & & & $\begin{array}{l}7.98^{* * * *} \\
(2.10)\end{array}$ & $\begin{array}{l}4.56^{* *} \\
(2.05)\end{array}$ & $\begin{array}{l}2.82 \\
(2.99)\end{array}$ \\
\hline Left & & & $\begin{array}{c}11.43^{* * *} \\
(1.51)\end{array}$ & $\begin{array}{l}6.95^{* * *} \\
(1.47)\end{array}$ & $\begin{array}{l}3.30^{*} \\
(1.90)\end{array}$ \\
\hline Other party & & & $\begin{array}{l}-0.45 \\
(1.86)\end{array}$ & $\begin{array}{c}1.31 \\
(1.83)\end{array}$ & $\begin{array}{l}-2.50 \\
(2.31)\end{array}$ \\
\hline Temp. has not increased & & & & $\begin{array}{c}-5.84^{* * *} \\
(1.49)\end{array}$ & $\begin{array}{c}-8.01^{* * *} \\
(1.76)\end{array}$ \\
\hline Own country should lead & & & & $\begin{array}{c}9.64^{* * * *} \\
(1.27)\end{array}$ & $\begin{array}{l}6.51^{* * *} \\
(1.80)\end{array}$ \\
\hline Mitigate cost-efficient & & & & $\begin{array}{l}4.20^{* * *} \\
(1.26)\end{array}$ & $\begin{array}{l}3.27^{* *} \\
(1.64)\end{array}$ \\
\hline Supp. strict. env. pol. & & & & $\begin{array}{c}11.84^{* * *} \\
(1.19)\end{array}$ & $\begin{array}{c}10.24^{* * *} \\
(1.50)\end{array}$ \\
\hline $2019 \times$ Female & & & & & $\begin{array}{l}-2.82 \\
(2.37)\end{array}$ \\
\hline $2019 \times$ Age & & & & & $\begin{array}{c}0.12 \\
(0.08)\end{array}$ \\
\hline $2019 \times$ Adults & & & & & $\begin{array}{c}1.84 \\
(1.93)\end{array}$ \\
\hline $2019 \times$ Children & & & & & $\begin{array}{c}0.62 \\
(1.44)\end{array}$ \\
\hline $2019 \times$ High s. & & & & & $\begin{array}{l}2.36 \\
(3.74)\end{array}$ \\
\hline $2019 \times$ Post-hi. & & & & & $\begin{array}{l}2.96 \\
(4.14)\end{array}$ \\
\hline $2019 \times$ Univ & & & & & $\begin{array}{c}2.57 \\
(4.18)\end{array}$ \\
\hline $2019 \times$ Income & & & & & $\begin{array}{l}-0.001 \\
(0.08)\end{array}$ \\
\hline $2019 \times$ Centrist & & & & & $\begin{array}{c}2.22 \\
(4.01)\end{array}$ \\
\hline $2019 \times$ Left & & & & & $\begin{array}{l}6.25^{* *} \\
(3.02)\end{array}$ \\
\hline $2019 \times$ Other & & & & & $\begin{array}{c}6.01 \\
(3.89)\end{array}$ \\
\hline $2019 \times$ Temp. not inc. & & & & & $\begin{array}{c}4.49 \\
(3.27)\end{array}$ \\
\hline $2019 \times$ Own country & & & & & $\begin{array}{l}5.33^{*} \\
(2.73)\end{array}$ \\
\hline $2019 \times$ Mit. cost-efficient & & & & & $\begin{array}{l}2.05 \\
(2.49)\end{array}$ \\
\hline $2019 \times$ Stricter env. pol. & & & & & $\begin{array}{c}2.84 \\
(2.46)\end{array}$ \\
\hline Locational controls & No & Yes & Yes & Yes & Yes \\
\hline No. observations & 2,726 & 2,726 & 2,726 & 2,726 & 2,726 \\
\hline
\end{tabular}

Note: Dependent variable is WTP for $30 \%$ reduction of emissions. Standard errors in parentheses. ${ }^{*} p<0.1,{ }^{* *} p$ $<0.05,{ }^{* * *} p<0.01$.

Table A7. China: Marginal Effects from Interval Regression Model 


\begin{tabular}{|c|c|c|c|c|c|}
\hline & (1) & (2) & (3) & (4) & (5) \\
\hline \multirow[t]{2}{*}{2019 sample } & $13.14^{* * *}$ & $9.02^{* * * *}$ & $9.03^{* * *}$ & $8.31^{* * *}$ & $30.94^{* * * *}$ \\
\hline & $(0.91)$ & (1.02) & $(1.02)$ & $(1.02)$ & (4.37) \\
\hline \multirow[t]{2}{*}{ Female } & & -1.05 & -0.94 & -1.00 & 0.55 \\
\hline & & (1.07) & $(1.06)$ & (1.06) & $(0.46)$ \\
\hline \multirow{2}{*}{ Age } & & $-0.47^{* * *}$ & $-0.46^{* * *}$ & $-0.47^{* * * *}$ & 0.01 \\
\hline & & $(0.04)$ & $(0.04)$ & $(0.04)$ & $(0.02)$ \\
\hline \multirow[t]{2}{*}{ No. of adults } & & 0.44 & 0.45 & 0.52 & -0.11 \\
\hline & & $(0.54)$ & $(0.54)$ & $(0.53)$ & $(0.17)$ \\
\hline \multirow[t]{2}{*}{ No. of children } & & 1.80 & 1.87 & 1.77 & 0.36 \\
\hline & & (1.14) & (1.14) & (1.137) & $(0.32)$ \\
\hline \multirow[t]{2}{*}{ High school } & & $6.06^{* * *}$ & $6.07^{* * * *}$ & $5.37^{* * *}$ & -0.71 \\
\hline & & (1.17) & $(1.17)$ & (1.19) & $(0.48)$ \\
\hline \multirow[t]{2}{*}{ Post-high school } & & $8.30^{* * * *}$ & $7.98^{* * *}$ & $7.03^{* * * *}$ & -0.67 \\
\hline & & $(1.15)$ & $(1.17)$ & (1.188) & $(0.64)$ \\
\hline \multirow[t]{2}{*}{ University graduate } & & $13.98^{* * * *}$ & $13.10^{* * * *}$ & $12.16^{* * *}$ & 0.08 \\
\hline & & $(1.52)$ & (1.59) & (1.59) & $(0.91)$ \\
\hline \multirow[t]{2}{*}{ Income } & & 0.06 & 0.053 & 0.05 & $0.35^{* * *}$ \\
\hline & & $(0.04)$ & $(0.04)$ & $(0.04)$ & $(0.04)$ \\
\hline \multirow[t]{2}{*}{ Party member } & & & $3.68^{* *}$ & $3.08^{* *}$ & 0.06 \\
\hline & & & (1.43) & (1.43) & $(0.73)$ \\
\hline \multirow[t]{2}{*}{ Temp. has not increased } & & & & 2.28 & -0.36 \\
\hline & & & & (3.41) & $(0.47)$ \\
\hline \multirow[t]{2}{*}{ Own country should lead } & & & & $3.03^{* * *}$ & $1.46^{* * * *}$ \\
\hline & & & & $(1.11)$ & $(0.44)$ \\
\hline \multirow[t]{2}{*}{ Mitigate cost-efficient } & & & & $2.91^{* *}$ & 0.21 \\
\hline & & & & $(1.17)$ & $(0.50)$ \\
\hline \multirow[t]{2}{*}{ Supp. strict. env. pol. } & & & & $3.75^{* * * *}$ & 0.21 \\
\hline & & & & $(1.12)$ & $(0.45)$ \\
\hline \multirow{2}{*}{$2019 \times$ Female } & & & & & -1.89 \\
\hline & & & & & $(1.72)$ \\
\hline \multirow[t]{2}{*}{$2019 \times$ Age } & & & & & $-0.71^{* * *}$ \\
\hline & & & & & $(0.07)$ \\
\hline \multirow{2}{*}{$2019 \times$ Adults } & & & & & 0.72 \\
\hline & & & & & $(0.93)$ \\
\hline \multirow[t]{2}{*}{$2019 \times$ Children } & & & & & 1.47 \\
\hline & & & & & $(1.73)$ \\
\hline $2019 \times$ High s. & & & & & 2.33 \\
\hline & & & & & $(1.90)$ \\
\hline $2019 \times$ Post-hi. & & & & & 1.83 \\
\hline & & & & & $(2.86)$ \\
\hline $2019 \times$ Univ & & & & & 5.66 \\
\hline & & & & & (3.64) \\
\hline $2019 \times$ Income & & & & & $-0.30^{* * *}$ \\
\hline & & & & & $(0.07)$ \\
\hline $2019 \times$ Party mem & & & & & $7.50^{* * * *}$ \\
\hline & & & & & $(2.40)$ \\
\hline $2019 \times$ Temp. not inc. & & & & & 7.69 \\
\hline & & & & & $(7.76)$ \\
\hline $2019 \times$ Own country & & & & & 2.17 \\
\hline & & & & & $(2.38)$ \\
\hline $2019 \times$ Mit. cost-efficient & & & & & 3.02 \\
\hline & & & & & (1.89) \\
\hline $2019 \times$ Stricter env. pol. & & & & & $5.96^{* * * *}$ \\
\hline & & & & & $(2.26)$ \\
\hline Locational controls & No & Yes & Yes & Yes & Yes \\
\hline No. observations & 2,843 & 2,843 & 2,843 & 2,843 & 2,843 \\
\hline
\end{tabular}

Note: Dependent variable is WTP for 30\% reduction of emissions. Standard errors in parentheses. ${ }^{*} p<0.1,{ }^{* *} p$ $<0.05,{ }^{* * *} p<0.01$. 
Table A8. United States: Marginal Effects from Interval Regression Model

\begin{tabular}{|c|c|c|c|c|c|c|c|c|}
\hline & (1) & (2) & (3) & (4) & (1) & (2) & (3) & (4) \\
\hline & \multicolumn{4}{|c|}{$60 \%$ reduction compared with $30 \%$ reduction } & \multicolumn{4}{|c|}{$85 \%$ reduction compared with $60 \%$ reduction } \\
\hline 2019 sample & $\begin{array}{l}8.94^{* * * *} \\
(2.27)\end{array}$ & $\begin{array}{l}6.81^{* * *} \\
(1.88)\end{array}$ & $\begin{array}{l}7.20^{* * *} \\
(1.83)\end{array}$ & $\begin{array}{l}3.23^{* *} \\
(1.61)\end{array}$ & $\begin{array}{l}8.49^{* * *} \\
(2.10)\end{array}$ & $\begin{array}{l}6.62^{* * *} \\
(1.54)\end{array}$ & $\begin{array}{l}6.91^{* * *} \\
(1.49)\end{array}$ & $\begin{array}{l}3.54^{* * *} \\
(1.33)\end{array}$ \\
\hline Female & & $-4.84^{*}$ & $-5.47^{*}$ & $\begin{array}{l}-5.38^{* * *} \\
(2.45)\end{array}$ & & $\begin{array}{l}-3.94 \\
\end{array}$ & $\begin{array}{l}-4.43^{*} \\
(265)\end{array}$ & $\begin{array}{l}-4.27^{*} \\
(231)\end{array}$ \\
\hline Age & & $\begin{array}{l}-0.05 \\
(0.06)\end{array}$ & $\begin{array}{l}-0.04 \\
(0.06)\end{array}$ & $\begin{array}{l}0.003 \\
(0.06)\end{array}$ & & $\begin{array}{c}-0.08 \\
(0.06)\end{array}$ & $\begin{array}{l}-0.08 \\
(0.05)\end{array}$ & $\begin{array}{l}-0.04 \\
(0.06)\end{array}$ \\
\hline No. of adults & & $\begin{array}{c}1.01 \\
(1.71)\end{array}$ & $\begin{array}{c}0.76 \\
(1.66)\end{array}$ & $\begin{array}{c}1.11 \\
(1.48)\end{array}$ & & $\begin{array}{c}1.06 \\
(1.73)\end{array}$ & $\begin{array}{c}0.88 \\
(1.72)\end{array}$ & $\begin{array}{c}1.16 \\
(1.54)\end{array}$ \\
\hline No. of children & & $\begin{array}{c}-1.09 \\
(0.76)\end{array}$ & $\begin{array}{c}-0.92 \\
(0.78)\end{array}$ & $\begin{array}{c}-0.26 \\
(0.76)\end{array}$ & & $\begin{array}{c}-0.83 \\
(0.67)\end{array}$ & $\begin{array}{l}-0.71 \\
(0.67)\end{array}$ & $\begin{array}{c}-0.15 \\
(0.63)\end{array}$ \\
\hline High school & & $\begin{array}{c}-13.90 * \\
(7.89)\end{array}$ & $\begin{array}{l}-12.46 \\
(8.12)\end{array}$ & $\begin{array}{c}-12.21^{*} \\
(7.23)\end{array}$ & & $\begin{array}{l}-11.58 \\
(7.35)\end{array}$ & $\begin{array}{l}-10.47 \\
(7.65)\end{array}$ & $\begin{array}{l}-10.11 \\
(6.78)\end{array}$ \\
\hline Post-high school & & $\begin{array}{l}-11.72 \\
(7.90)\end{array}$ & $\begin{array}{l}-10.62 \\
(8.17)\end{array}$ & $\begin{array}{l}-10.70 \\
(7.35)\end{array}$ & & $\begin{array}{l}-10.48 \\
(7.29)\end{array}$ & $\begin{array}{c}-9.64 \\
(7.62)\end{array}$ & $\begin{array}{c}-9.59 \\
(6.82)\end{array}$ \\
\hline University graduate & & $\begin{array}{l}-8.07 \\
(8.92)\end{array}$ & $\begin{array}{c}-7.53 \\
(9.03)\end{array}$ & $\begin{array}{c}-9.01 \\
(8.25)\end{array}$ & & $\begin{array}{c}-9.13 \\
(8.17)\end{array}$ & $\begin{array}{l}-8.70 \\
(8.32)\end{array}$ & $\begin{array}{c}-9.79 \\
(7.59)\end{array}$ \\
\hline Income & & $\begin{array}{l}0.10^{* * *} \\
(0.02)\end{array}$ & $\begin{array}{c}0.10^{* * *} \\
(0.02)\end{array}$ & $\begin{array}{c}0.09^{* * * *} \\
(0.02)\end{array}$ & & $\begin{array}{l}0.10^{* * * *} \\
(0.02)\end{array}$ & $\begin{array}{l}0.10^{* * * *} \\
(0.02)\end{array}$ & $\begin{array}{c}0.09^{* * * *} \\
(0.02)\end{array}$ \\
\hline No response income & & $\begin{array}{c}18.17 \\
(1381)\end{array}$ & $\begin{array}{c}19.66 \\
(13.87)\end{array}$ & $\begin{array}{c}17.90 \\
(12.22)\end{array}$ & & $\begin{array}{c}18.02 \\
(13.87)\end{array}$ & $\begin{array}{c}19.15 \\
(13.93)\end{array}$ & $\begin{array}{c}17.58 \\
(12.36)\end{array}$ \\
\hline Democrat & & & $\begin{array}{c}10.74^{* * * *} \\
(3.46)\end{array}$ & $\begin{array}{l}2.560 \\
(4.05)\end{array}$ & & & $\begin{array}{l}7.88^{* *} \\
(3.17)\end{array}$ & $\begin{array}{c}1.131 \\
(3.91)\end{array}$ \\
\hline Other party & & & $\begin{array}{c}-0.09 \\
(4.16)\end{array}$ & $\begin{array}{l}-1.10 \\
(3.76)\end{array}$ & & & & $\begin{array}{c}-0.78 \\
(3.77)\end{array}$ \\
\hline Independent & & & $\begin{array}{c}2.67 \\
(3.57)\end{array}$ & $\begin{array}{c}-0.33 \\
(3.61)\end{array}$ & & & $\begin{array}{c}1.55 \\
(3.42)\end{array}$ & $\begin{array}{c}-0.95 \\
(3.52)\end{array}$ \\
\hline Temp. has not increased & & & & $\begin{array}{c}-3.47^{* * * *} \\
(1.26)\end{array}$ & & & & $\begin{array}{c}-2.30^{* * *} \\
(1.06)\end{array}$ \\
\hline Own country should lead & & & & $\begin{array}{l}3.78^{* * *} \\
(1.78)\end{array}$ & & & & $\begin{array}{l}3.29^{* *} \\
(1.62)\end{array}$ \\
\hline Mitigate cost-efficient & & & & $\begin{array}{c}5.77 \\
(3.53)\end{array}$ & & & & $\begin{array}{c}6.00^{*} \\
(3.39)\end{array}$ \\
\hline Supp. strict. env. pol. & & & & $\begin{array}{c}14.57^{* * *} \\
(2.17)\end{array}$ & & & & $\begin{array}{c}11.94^{* * * *} \\
(2.11)\end{array}$ \\
\hline Locational controls & No & Yes & Yes & Yes & No & Yes & Yes & Yes \\
\hline No. observations & 2,458 & 2,458 & 2,458 & 2,458 & 2,458 & 2,458 & 2,458 & 2,458 \\
\hline
\end{tabular}

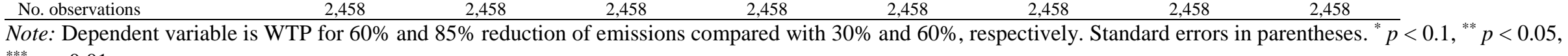
${ }^{* * *} p<0.01$ 
Table A9. Sweden: Marginal Effects from Interval Regression Model

\begin{tabular}{|c|c|c|c|c|c|c|c|c|}
\hline & $(1)$ & (2) & (3) & (4) & (1) & (2) & (3) & (4) \\
\hline & \multicolumn{4}{|c|}{$60 \%$ reduction compared with $30 \%$ reduction } & \multicolumn{4}{|c|}{$85 \%$ reduction compared with $60 \%$ reduction } \\
\hline 2019 sample & $3.89^{* * * *}$ & $3.84^{* * * *}$ & $4.49^{* * *}$ & $5.49^{* * *}$ & $2.93^{* * * *}$ & $2.91^{* * *}$ & $3.59^{* * *}$ & $4.32^{* * *}$ \\
\hline Female & & $\begin{array}{c}-4.42^{* * *} \\
(1.12)\end{array}$ & $\begin{array}{c}-4.64^{* * *} \\
(1.12)\end{array}$ & $\begin{array}{c}-4.62^{* * *} \\
(1.11)\end{array}$ & & $\begin{array}{c}-3.95^{* * *} \\
(1.08)\end{array}$ & $\begin{array}{c}(1.02) \\
-4.22^{* * *} \\
(1.07)\end{array}$ & $\begin{array}{c}-3.87^{* * * *} \\
(1.03)\end{array}$ \\
\hline Age & & $\begin{array}{c}-0.20^{* * *} \\
(0.04)\end{array}$ & $\begin{array}{c}-0.20^{* * *} \\
(0.04)\end{array}$ & $\begin{array}{c}-0.20^{* * * *} \\
(0.04)\end{array}$ & & $\begin{array}{c}-0.24^{* * * *} \\
(0.04)\end{array}$ & $\begin{array}{c}-0.24 * * * \\
(0.04)\end{array}$ & $\begin{array}{c}-0.24 * * * \\
(0.04)\end{array}$ \\
\hline No. of adults & & $\begin{array}{l}-0.03 \\
(1.45)\end{array}$ & $\begin{array}{c}0.10 \\
(1.41)\end{array}$ & $\begin{array}{c}0.47 \\
(1.35)\end{array}$ & & $\begin{array}{c}0.31 \\
(1.94)\end{array}$ & $\begin{array}{c}0.41 \\
(1.90)\end{array}$ & $\begin{array}{c}0.72 \\
(1.84)\end{array}$ \\
\hline No. of children & & $\begin{array}{c}-1.92 * * * \\
(0.68)\end{array}$ & $\begin{array}{c}-1.89 * * * \\
(0.68)\end{array}$ & $\begin{array}{c}-1.70^{* *} \\
(0.67)\end{array}$ & & $\begin{array}{c}-1.74^{* * *} \\
(0.64)\end{array}$ & $\begin{array}{c}-1.69 * * * \\
(0.64)\end{array}$ & $\begin{array}{l}-1.53^{* *} \\
(0.628)\end{array}$ \\
\hline High school & & $\begin{array}{c}1.92 \\
(1.79)\end{array}$ & $\begin{array}{c}2.34 \\
(1.84)\end{array}$ & $\begin{array}{c}1.75 \\
(1.82)\end{array}$ & & $\begin{array}{l}1.14 \\
(1.75)\end{array}$ & $\begin{array}{c}1.69 \\
(1.79)\end{array}$ & $\begin{array}{c}1.19 \\
(1.77)\end{array}$ \\
\hline Post-high school & & $\begin{array}{c}2.38 \\
(2.02)\end{array}$ & $\begin{array}{c}2.91 \\
(2.07)\end{array}$ & $\begin{array}{c}2.06 \\
(2.04)\end{array}$ & & $\begin{array}{c}1.03 \\
(1.96)\end{array}$ & $\begin{array}{l}1.70 \\
(2.01)\end{array}$ & $\begin{array}{c}0.97 \\
(2.00)\end{array}$ \\
\hline University graduate & & $\begin{array}{c}7.93 * * * \\
(2.07)\end{array}$ & $\begin{array}{c}8.25 * * * \\
(2.11)\end{array}$ & $\begin{array}{c}6.30 * * * \\
(2.06)\end{array}$ & & $\begin{array}{c}6.51^{* * * *} \\
(2.09)\end{array}$ & $\begin{array}{c}7.12 * * * \\
(2.12)\end{array}$ & $\begin{array}{c}5.46 * * * \\
(2.09)\end{array}$ \\
\hline Income & & $\begin{array}{c}0.24 * * * \\
(0.04)\end{array}$ & $\begin{array}{c}0.24 * * * \\
(0.04)\end{array}$ & $\begin{array}{c}0.23^{* * *} \\
(0.04)\end{array}$ & & $\begin{array}{c}0.15^{* * *} \\
(0.05)\end{array}$ & $\begin{array}{c}0.15^{* * * *} \\
(0.04)\end{array}$ & $\begin{array}{c}0.15^{* * * *} \\
(0.05)\end{array}$ \\
\hline Centrist & & & $\begin{array}{c}5.67 * * * \\
(1.98)\end{array}$ & $\begin{array}{c}3.16 \\
(1.94)\end{array}$ & & & $\begin{array}{l}3.63^{* *} \\
(1.50)\end{array}$ & $\begin{array}{c}1.82 \\
(1.45)\end{array}$ \\
\hline Left & & & $\begin{array}{c}8.25 * * * \\
(1.39)\end{array}$ & $\begin{array}{c}4.93 * * * \\
(1.34)\end{array}$ & & & $\begin{array}{c}8.22 * * * \\
(1.34)\end{array}$ & $\begin{array}{c}5.81 * * * \\
(1.27)\end{array}$ \\
\hline Other party & & & $\begin{array}{l}-1.32 \\
(1.65)\end{array}$ & $\begin{array}{l}-0.01 \\
(1.62)\end{array}$ & & & $\begin{array}{c}0.51 \\
(1.72)\end{array}$ & $\begin{array}{c}1.74 \\
(1.72)\end{array}$ \\
\hline Temp. has not increased & & & & $\begin{array}{c}-5.01 * * * \\
(1.30)\end{array}$ & & & & $\begin{array}{c}-3.17^{* *} \\
(1.52)\end{array}$ \\
\hline Own country should lead & & & & $\begin{array}{c}6.30^{* * *} \\
(1.40)\end{array}$ & & & & $\begin{array}{l}3.14^{* *} \\
(1.44)\end{array}$ \\
\hline Mitigate cost-efficient & & & & $\begin{array}{l}2.85 * * \\
(1.15)\end{array}$ & & & & $\begin{array}{c}2.54 * * \\
(1.07)\end{array}$ \\
\hline Supp. strict. env. pol. & & & & $\begin{array}{c}9.28 * * * \\
(1.17)\end{array}$ & & & & $\begin{array}{c}8.77^{* * *} \\
(1.16)\end{array}$ \\
\hline Locational controls & No & Yes & Yes & Yes & No & Yes & Yes & Yes \\
\hline No. observations & 2,726 & 2,726 & 2,726 & 2,726 & 2,726 & 2,726 & 2,726 & 2,726 \\
\hline
\end{tabular}

Note: Dependent variable is WTP for $60 \%$ and $85 \%$ reduction of emissions compared with $30 \%$ and $60 \%$, respectively. Standard errors in parentheses. ${ }^{*} p<0.1,{ }^{* *} p<0.05$, ${ }^{* * *} p<0.01$. 
Table A10. China: Marginal Effects from Interval Regression Model

\begin{tabular}{|c|c|c|c|c|c|c|c|c|}
\hline & $(1)$ & $(2)$ & (3) & (4) & $(1)$ & (2) & (3) & (4) \\
\hline & \multicolumn{4}{|c|}{$60 \%$ reduction compared with $30 \%$ reduction } & \multicolumn{4}{|c|}{$85 \%$ reduction compared with $60 \%$ reduction } \\
\hline 2019 sample & $15.73^{* * *}$ & $11.99 * * *$ & $12.00^{* * *}$ & $11.38^{* * *}$ & $16.73^{* * *}$ & $13.92 * * *$ & $13.94^{* * *}$ & $13.33^{* * *}$ \\
\hline Female & & $\begin{array}{c}(1.02) \\
-1.36 \\
(1.0)\end{array}$ & $\begin{array}{l}(1.02) \\
-1.19 \\
(1.06)\end{array}$ & $\begin{array}{l}(1.02) \\
-1.24 \\
(1.04)\end{array}$ & $(0.99)$ & $\begin{array}{l}(1.20) \\
-1.06\end{array}$ & $\begin{array}{c}(1.19) \\
-0.84\end{array}$ & $\begin{array}{l}(1.18) \\
-0.88 \\
-1.12)\end{array}$ \\
\hline Age & & $\begin{array}{c}-0.47^{* * * *} \\
(0.04)\end{array}$ & $\begin{array}{c}-0.47 * * * \\
(0.04)\end{array}$ & $\begin{array}{c}-0.48 * * * \\
(0.04)\end{array}$ & & $\begin{array}{c}-0.45^{* * * *} \\
(0.04)\end{array}$ & $\begin{array}{c}-0.44 * * * \\
(0.04)\end{array}$ & $\begin{array}{c}-0.45^{* * *} \\
(0.04)\end{array}$ \\
\hline No. of adults & & $\begin{array}{l}-0.02 \\
(0.53)\end{array}$ & $\begin{array}{l}-0.01 \\
(0.53)\end{array}$ & $\begin{array}{c}0.05 \\
(0.53)\end{array}$ & & $\begin{array}{l}0.004 \\
(0.59)\end{array}$ & $\begin{array}{c}0.02 \\
(0.58)\end{array}$ & $\begin{array}{c}0.08 \\
(0.58)\end{array}$ \\
\hline No. of kids & & $\begin{array}{c}0.55 \\
(0.76)\end{array}$ & $\begin{array}{c}0.65 \\
(0.75)\end{array}$ & $\begin{array}{c}0.57 \\
(0.75)\end{array}$ & & $\begin{array}{c}0.58 \\
(0.81)\end{array}$ & $\begin{array}{c}0.71 \\
(0.80)\end{array}$ & $\begin{array}{c}0.63 \\
(0.80)\end{array}$ \\
\hline High school & & $\begin{array}{c}6.58^{* * * *} \\
(1.18)\end{array}$ & $\begin{array}{c}6.61^{* * * *} \\
(1.18)\end{array}$ & $\begin{array}{c}6.04 * * * \\
(1.196)\end{array}$ & & $\begin{array}{c}6.65 * * * \\
(1.28)\end{array}$ & $\begin{array}{c}6.69 * * * \\
(1.28)\end{array}$ & $\begin{array}{c}6.11^{* * * *} \\
(1.29)\end{array}$ \\
\hline Post-high school & & $\begin{array}{c}8.21 * * * \\
(1.19)\end{array}$ & $\begin{array}{c}7.72 * * * \\
(1.21)\end{array}$ & $\begin{array}{c}6.91 * * * \\
(1.23)\end{array}$ & & $\begin{array}{c}9.35 * * * \\
(1.28)\end{array}$ & $\begin{array}{c}8.74^{* * * *} \\
(1.28)\end{array}$ & $\begin{array}{c}7.93 * * * \\
(1.31)\end{array}$ \\
\hline University graduate & & $\begin{array}{c}13.44^{* * *} \\
(1.53)\end{array}$ & $\begin{array}{c}12.07 * * * \\
(1.59)\end{array}$ & $\begin{array}{c}11.27 * * * \\
(1.60)\end{array}$ & & $\begin{array}{c}14.39 * * * \\
(1.67)\end{array}$ & $\begin{array}{c}12.70^{* * * *} \\
(1.67)\end{array}$ & $\begin{array}{c}11.89 * * * * \\
(1.68)\end{array}$ \\
\hline Income & & $\begin{array}{c}0.06 \\
(0.04)\end{array}$ & $\begin{array}{c}0.05 \\
(0.04)\end{array}$ & $\begin{array}{c}0.05 \\
(0.04)\end{array}$ & & $\begin{array}{c}0.02 \\
(0.05)\end{array}$ & $\begin{array}{l}0.002 \\
(0.05)\end{array}$ & $\begin{array}{l}0.001 \\
(0.05)\end{array}$ \\
\hline Party member & & & $\begin{array}{l}5.82^{* * * *} \\
(1.687)\end{array}$ & $\begin{array}{c}5.27 * * * \\
(1.68)\end{array}$ & & & $\begin{array}{c}7.25 * * * \\
(1.85)\end{array}$ & $\begin{array}{c}6.71 * * * \\
(1.85)\end{array}$ \\
\hline Temp. has not increased & & & & $\begin{array}{c}3.36 \\
(3.44)\end{array}$ & & & & $\begin{array}{c}2.61 \\
(2.67)\end{array}$ \\
\hline Own country should lead & & & & $\begin{array}{c}2.75^{* * *} \\
(1.02)\end{array}$ & & & & $\begin{array}{c}2.78 * * * \\
(1.03)\end{array}$ \\
\hline Mitigate cost-efficient & & & & $\begin{array}{l}2.52 * * \\
(1.17)\end{array}$ & & & & $\begin{array}{c}2.06 \\
(1.26)\end{array}$ \\
\hline Supp. strict. env. pol. & & & & $\begin{array}{c}3.55^{* * *} \\
(1.02) \\
\end{array}$ & & & & $\begin{array}{c}3.46 * * * \\
(1.07) \\
\end{array}$ \\
\hline Locational controls & No & Yes & Yes & Yes & No & Yes & Yes & Yes \\
\hline No. observations & 2,843 & 2,843 & 2.843 & 2.843 & 2,843 & 2,843 & 2,843 & 2,843 \\
\hline
\end{tabular}

Note: Dependent variable is WTP for $60 \%$ and $85 \%$ reduction of emissions compared with $30 \%$ and $60 \%$, respectively. Standard errors in parentheses. ${ }^{*} p<0.1,{ }^{* *} p<0.05$,

${ }^{* * *} p<0.01$. 
Table A11. Monthly Household WTP in PPP Dollars (Survey Weights) among Democrats, Republicans, and Independents

\begin{tabular}{|c|c|c|c|c|c|c|}
\hline \multirow[b]{2}{*}{ Reduction level } & \multicolumn{2}{|c|}{ Democrats } & \multicolumn{2}{|c|}{ Republicans } & \multicolumn{2}{|c|}{ Independents } \\
\hline & Mean & St. dev. & Mean & St. dev. & Mean & St. dev. \\
\hline \multicolumn{7}{|c|}{2019} \\
\hline $30 \%$ reduction & 45 & 59 & 15 & 35 & 25 & 45 \\
\hline $60 \%$ reduction & 77 & 95 & 29 & 69 & 47 & 79 \\
\hline $85 \%$ reduction & 103 & 129 & 40 & 103 & 65 & 111 \\
\hline Share zero WTP & 0.05 & & 0.37 & & 0.18 & \\
\hline \multicolumn{7}{|c|}{2009} \\
\hline $30 \%$ reduction & 28 & 48 & 10 & 24 & 20 & 43 \\
\hline $60 \%$ reduction & 47 & 81 & 15 & 32 & 33 & 70 \\
\hline $85 \%$ reduction & 61 & 108 & 18 & 37 & 42 & 91 \\
\hline Share zero WTP & 0.12 & & 0.35 & & 0.25 & \\
\hline
\end{tabular}

Table A12. Absolute and Relative Differences in WTP for Three Different Comparisons of Political Preferences in the US Sample between 2019 and 2009

\begin{tabular}{lccc}
\hline & 30\% reduction & 60\% reduction & 85\% reduction \\
\hline Democrats - Republicans & & Difference in absolute level of WTP & 20.41 \\
Democrats - Independents & 10.98 & $16.12 *$ & 19.25 \\
Independents - Republicans & 10.68 & 15.17 & 1.15 \\
\hline & 0.30 & 0.95 & Difference in relative levels of WTP \\
\hline Democrats / Republicans & & -0.46 & -0.75 \\
Democrats / Independents & 0.00 & 0.19 & 0.14 \\
Independents / Republicans & 0.32 & -0.53 & -0.67 \\
\hline
\end{tabular}

Note: $P$-values for the z-test were retrieved using the Krinsky and Robb (1986) method. Survey weights based on the population level of educational attainment are applied for both political parties and independents in the United States in both 2009 and 2019 (survey weights are available on request). We used 1,000 draws from a normal distribution with mean and variances given by the estimated mean and variance of WTP. ${ }^{*} p<0.1,{ }^{* *} p<0.05,{ }^{* * *} p<0.01$. 
Table A13. Attitudes toward Climate Change and Policy among Democrats, Republicans, and Independents in the United States

\begin{tabular}{|c|c|c|c|c|c|c|c|c|c|c|}
\hline & & \multicolumn{2}{|c|}{ Democrats } & \multirow[b]{2}{*}{$p$-val } & \multicolumn{2}{|c|}{ Republicans } & \multicolumn{4}{|c|}{ Independents } \\
\hline & & 2009 & 2019 & & 2009 & 2019 & $p$-val & 2009 & 2019 & $p$-val \\
\hline $\begin{array}{l}\text { No temperature } \\
\text { increase }\end{array}$ & $\begin{array}{l}\text { The temperature has not } \\
\text { increased globally. }\end{array}$ & $10 \%$ & $5 \%$ & 0.001 & $40 \%$ & $32 \%$ & 0.008 & $28 \%$ & $17 \%$ & 0.058 \\
\hline $\begin{array}{l}\text { Humans affect } \\
\text { temperature } \\
\text { increase }\end{array}$ & $\begin{array}{l}\text { Humans have affected the } \\
\text { temperature increase. }\end{array}$ & $86 \%$ & $97 \%$ & 0.000 & $57 \%$ & $68 \%$ & 0.008 & $72 \%$ & $79 \%$ & 0.240 \\
\hline $\begin{array}{l}\text { Cannot stop } \\
\text { climate change }\end{array}$ & $\begin{array}{l}\text { We cannot do anything to stop } \\
\text { climate change. }\end{array}$ & $14 \%$ & $7 \%$ & 0.030 & $22 \%$ & $21 \%$ & 0.935 & $16 \%$ & $13 \%$ & 0.354 \\
\hline $\begin{array}{l}\text { Can mitigate but } \\
\text { not stop }\end{array}$ & $\begin{array}{c}\text { We can mitigate but not stop } \\
\text { climate change. }\end{array}$ & $68 \%$ & $73 \%$ & 0.246 & $51 \%$ & $55 \%$ & 0.327 & $59 \%$ & $66 \%$ & 0.194 \\
\hline $\begin{array}{l}\text { Can stop climate } \\
\text { change }\end{array}$ & We can stop climate change. & $14 \%$ & $17 \%$ & 0.317 & $6 \%$ & $7 \%$ & 0.680 & $9 \%$ & $15 \%$ & 0.200 \\
\hline Climate denial & The climate is not changing. & $3 \%$ & $1 \%$ & 0.005 & $21 \%$ & $17 \%$ & 0.229 & $16 \%$ & $4 \%$ & 0.000 \\
\hline $\begin{array}{l}\text { Own country } \\
\text { should reduce }\end{array}$ & $\begin{array}{l}\text { Own country should reduce } \\
\text { carbon emissions, even if other } \\
\text { countries do not reduce their } \\
\text { carbon emissions. }\end{array}$ & $80 \%$ & $96 \%$ & 0.000 & $58 \%$ & $61 \%$ & 0.404 & $68 \%$ & $74 \%$ & 0.342 \\
\hline $\begin{array}{l}\text { Reduce where it is } \\
\text { cheap }\end{array}$ & $\begin{array}{l}\text { Own country should primarily } \\
\text { use public funding to reduce } \\
\text { carbon emissions wherever it } \\
\text { is cheapest, even if it means in } \\
\text { another country. }\end{array}$ & $18 \%$ & $32 \%$ & 0.001 & $14 \%$ & $17 \%$ & 0.416 & $17 \%$ & $29 \%$ & 0.032 \\
\hline $\begin{array}{l}\text { Reduce in own } \\
\text { country }\end{array}$ & $\begin{array}{l}\text { Own country should primarily } \\
\text { use public funding to reduce } \\
\text { carbon emissions in own } \\
\text { country. }\end{array}$ & $51 \%$ & $54 \%$ & 0.488 & $37 \%$ & $45 \%$ & 0.058 & $43 \%$ & $42 \%$ & 0.818 \\
\hline No opinion & No opinion or other opinion. & $32 \%$ & $14 \%$ & 0.000 & $49 \%$ & $38 \%$ & 0.014 & $40 \%$ & $30 \%$ & 0.072 \\
\hline Primarily mitigate & $\begin{array}{l}\text { Countries in the world should } \\
\text { deal with climate change } \\
\text { primarily by reducing carbon } \\
\text { emissions. }\end{array}$ & $74 \%$ & $88 \%$ & 0.000 & $42 \%$ & $50 \%$ & 0.069 & $58 \%$ & $60 \%$ & 0.812 \\
\hline $\begin{array}{l}\text { Primarily } \\
\text { adaptation }\end{array}$ & $\begin{array}{l}\text { Countries in the world should } \\
\text { deal with climate change } \\
\text { primarily by adaptation. }\end{array}$ & $13 \%$ & $10 \%$ & 0.531 & $16 \%$ & $20 \%$ & 0.176 & $18 \%$ & $25 \%$ & 0.221 \\
\hline Do nothing & $\begin{array}{l}\text { Do nothing, because I don't } \\
\text { consider climate change to be } \\
\text { a problem. }\end{array}$ & $14 \%$ & $2 \%$ & 0.000 & $42 \%$ & $30 \%$ & 0.003 & $24 \%$ & $15 \%$ & 0.009 \\
\hline $\begin{array}{l}\text { Trustworthy } \\
\text { information }\end{array}$ & $\begin{array}{l}\text { The information given in the } \\
\text { survey regarding climate } \\
\text { change is trustworthy. }\end{array}$ & $67 \%$ & $87 \%$ & 0.000 & $32 \%$ & $41 \%$ & 0.037 & $49 \%$ & $57 \%$ & 0.142 \\
\hline $\begin{array}{l}\text { Prioritize } \\
\text { environment }\end{array}$ & $\begin{array}{l}\text { We should prioritize } \\
\text { environmental improvements, } \\
\text { even if we lose jobs. }\end{array}$ & $52 \%$ & $88 \%$ & 0.000 & $30 \%$ & $37 \%$ & 0.069 & $39 \%$ & $55 \%$ & 0.005 \\
\hline No. observations & & 368 & 500 & & 248 & 390 & & 284 & 436 & \\
\hline
\end{tabular}

Note: $P$-values for t-test of difference in means based on survey weights. 
Table A14. Monthly Household WTP in PPP Dollars (Survey Weights among Swedish LeftWing Voters, Right-Wing Voters, and Centrist Voters)

\begin{tabular}{|c|c|c|c|c|c|c|}
\hline \multirow[b]{2}{*}{ Reduction level } & \multicolumn{2}{|c|}{ Left-wing voters } & \multicolumn{2}{|c|}{ Right-wing voters } & \multicolumn{2}{|c|}{ Centrist voters } \\
\hline & Mean & Std. dev. & Mean & Std. dev. & Mean & Std. dev. \\
\hline \multicolumn{7}{|c|}{2019} \\
\hline $30 \%$ reduction & 38 & 48 & 21 & 35 & 33 & 43 \\
\hline $60 \%$ reduction & 68 & 88 & 40 & 66 & 60 & 79 \\
\hline $85 \%$ reduction & 94 & 127 & 54 & 92 & 79 & 104 \\
\hline Share of zero WTP & 0.04 & & 0.18 & & 0.08 & \\
\hline \multicolumn{7}{|c|}{2009} \\
\hline $30 \%$ reduction & 26 & 36 & 21 & 34 & 26 & 35 \\
\hline $60 \%$ reduction & 49 & 67 & 37 & 59 & 48 & 66 \\
\hline $85 \%$ reduction & 67 & 99 & 48 & 83 & 63 & 90 \\
\hline Share of zero WTP & 0.04 & & 0.12 & & 0.06 & \\
\hline
\end{tabular}

Table A15. Absolute and Relative Differences in WTP for Three Different Comparisons of Political Preferences in the Swedish Sample between 2019 and 2009

\begin{tabular}{|c|c|c|c|}
\hline & $30 \%$ reduction & $60 \%$ reduction & $85 \%$ reduction \\
\hline & \multicolumn{3}{|c|}{ Difference in absolute level of WTP } \\
\hline Left - Right & $11.6^{* * *}$ & $16.4^{* *}$ & $21.6^{* *}$ \\
\hline Left - Centrist & 4.5 & 7.8 & 11.2 \\
\hline \multirow[t]{2}{*}{ Centrist - Right } & 7.2 & 8.6 & 10.4 \\
\hline & \multicolumn{3}{|c|}{ Difference in relative levels of WTP } \\
\hline Left / Right & $0.55^{* *}$ & $0.38^{*}$ & 0.36 \\
\hline Left / Centrist & 0.13 & 0.13 & 0.13 \\
\hline Centrist / Right & 0.34 & 0.19 & 0.16 \\
\hline
\end{tabular}

Note: P-values for the z-test were retrieved using the Krinsky and Robb (1986) method. Survey weights based on the population level of educational attainment are applied for all political groups in Sweden in both 2009 and 2019 (survey weights for political parties are available on request). We used 1,000 draws from a normal distribution with mean and variances given by the estimated mean and variance of WTP. ${ }^{*} p<0.1,{ }^{* *} p<0.05,{ }^{* * *} p<0.01$.

Table A16. Absolute and Relative Differences in WTP for Three Different Comparisons of Political Preferences in the Swedish Sample (excluding the party Sweden Democrats)

\begin{tabular}{|c|c|c|c|}
\hline & $30 \%$ reduction & $60 \%$ reduction & $85 \%$ reduction \\
\hline & \multicolumn{3}{|c|}{ Panel A. Difference in absolute level of WTP } \\
\hline Left - Right & $9.1^{* *}$ & 10.7 & $27.2^{* *}$ \\
\hline Left - Centrists & 4.5 & 7.7 & 11.2 \\
\hline \multirow{2}{*}{ Centrists - Right } & 4.6 & 2.9 & 16.0 \\
\hline & \multicolumn{3}{|c|}{ Panel B. Difference in relative levels of WTP } \\
\hline Left / Right & 0.33 & 0.18 & $0.50^{*}$ \\
\hline Left / Centrists & 0.13 & 0.13 & 0.13 \\
\hline Centrists / Right & 0.16 & 0.03 & 0.29 \\
\hline
\end{tabular}

Note: Excludes the populistic party Sweden Democrats. Survey weights based on the correct level of educational attainment of the population are adjusted after excluding the Swedish Democrats from the comparisons (these weights are available on request). We used 1,000 draws from a normal distribution with mean and variances given by the estimated mean and variance of WTP. ${ }^{*} p<0.1,{ }^{* *} p<0.05,{ }^{* * *} p<0.01$. 
Table A17. Attitudes toward Climate Change and Policy among Left-Wing, Centrist and Right-Wing Voters in Sweden

\begin{tabular}{|c|c|c|c|c|c|c|c|c|c|c|}
\hline & & & & & & & & Centrist & & \\
\hline & & 2009 & 2019 & $p$-value & 2009 & 2019 & $p$-value & 2009 & 2019 & $p$-value \\
\hline $\begin{array}{l}\text { No temperature } \\
\text { increase }\end{array}$ & $\begin{array}{l}\text { The temperature has not increased } \\
\text { globally. }\end{array}$ & $5 \%$ & $2 \%$ & 0.037 & $7 \%$ & $10 \%$ & 0.146 & $3 \%$ & $3 \%$ & 0.794 \\
\hline $\begin{array}{l}\text { Humans affect } \\
\text { temperature } \\
\text { increase }\end{array}$ & $\begin{array}{l}\text { Humans have affected the temperature } \\
\text { increase. }\end{array}$ & $96 \%$ & $98 \%$ & 0.024 & $92 \%$ & $93 \%$ & 0.420 & $99 \%$ & $98 \%$ & 0.471 \\
\hline $\begin{array}{l}\text { Cannot stop } \\
\text { climate change }\end{array}$ & $\begin{array}{l}\text { We cannot do anything to stop climate } \\
\text { change. }\end{array}$ & $6 \%$ & $4 \%$ & 0.164 & $8 \%$ & $7 \%$ & 0.610 & $1 \%$ & $6 \%$ & 0.048 \\
\hline $\begin{array}{l}\text { Can mitigate } \\
\text { but not stop }\end{array}$ & $\begin{array}{l}\text { We can mitigate but not stop climate } \\
\text { change. }\end{array}$ & $80 \%$ & $79 \%$ & 0.804 & $82 \%$ & $77 \%$ & 0.120 & $83 \%$ & $84 \%$ & 0.723 \\
\hline $\begin{array}{l}\text { Can stop } \\
\text { climate change }\end{array}$ & We can stop climate change. & $13 \%$ & $17 \%$ & 0.119 & $6 \%$ & $11 \%$ & 0.014 & $15 \%$ & $9 \%$ & 0.109 \\
\hline Climate denial & The climate is not changing. & $2 \%$ & $1 \%$ & 0.006 & $3 \%$ & $2 \%$ & 0.474 & $0 \%$ & $1 \%$ & 0.318 \\
\hline $\begin{array}{l}\text { Own country } \\
\text { should reduce }\end{array}$ & $\begin{array}{l}\text { Own country should reduce carbon } \\
\text { emissions, even if other countries do not } \\
\text { reduce their carbon emissions. }\end{array}$ & $89 \%$ & $89 \%$ & 0.712 & $73 \%$ & $60 \%$ & 0.001 & $79 \%$ & $83 \%$ & 0.399 \\
\hline $\begin{array}{l}\text { Reduce where it } \\
\text { is cheap }\end{array}$ & $\begin{array}{l}\text { Own country should primarily use } \\
\text { public funding to reduce carbon } \\
\text { emissions wherever it is cheapest, even } \\
\text { if it means in another country. }\end{array}$ & $38 \%$ & $36 \%$ & 0.559 & $46 \%$ & $50 \%$ & 0.273 & $60 \%$ & $39 \%$ & 0.000 \\
\hline $\begin{array}{l}\text { Reduce in own } \\
\text { country }\end{array}$ & $\begin{array}{l}\text { Own country should primarily use } \\
\text { public funding to reduce carbon } \\
\text { emissions in own country. }\end{array}$ & $48 \%$ & $47 \%$ & 0.703 & $32 \%$ & $27 \%$ & 0.148 & $32 \%$ & $42 \%$ & 0.086 \\
\hline No opinion & No opinion or other opinion. & $13 \%$ & $16 \%$ & 0.191 & $22 \%$ & $23 \%$ & 0.759 & $8 \%$ & $19 \%$ & 0.010 \\
\hline $\begin{array}{l}\text { Primarily } \\
\text { mitigate }\end{array}$ & $\begin{array}{l}\text { Countries in the world should deal with } \\
\text { climate change primarily by reducing } \\
\text { carbon emissions. }\end{array}$ & $93 \%$ & $92 \%$ & 0.727 & $75 \%$ & $74 \%$ & 0.823 & $91 \%$ & $88 \%$ & 0.393 \\
\hline $\begin{array}{l}\text { Primarily } \\
\text { adaptation }\end{array}$ & $\begin{array}{l}\text { Countries in the world should deal with } \\
\text { climate change primarily by adaptation. }\end{array}$ & $5 \%$ & $6 \%$ & 0.554 & $18 \%$ & $20 \%$ & 0.573 & $6 \%$ & $12 \%$ & 0.180 \\
\hline Do nothing & $\begin{array}{l}\text { Do nothing, because I don't consider } \\
\text { climate change to be a problem. }\end{array}$ & $2 \%$ & $1 \%$ & 0.729 & $7 \%$ & $6 \%$ & 0.571 & $2 \%$ & $1 \%$ & 0.373 \\
\hline $\begin{array}{l}\text { Trustworthy } \\
\text { information }\end{array}$ & $\begin{array}{l}\text { The information given in the survey } \\
\text { regarding climate change is trustworthy. }\end{array}$ & $86 \%$ & $87 \%$ & 0.561 & $77 \%$ & $71 \%$ & 0.079 & $87 \%$ & $88 \%$ & 0.764 \\
\hline $\begin{array}{l}\text { Prioritize } \\
\text { environment }\end{array}$ & $\begin{array}{l}\text { We should prioritize environmental } \\
\text { improvements, even if we lose jobs. }\end{array}$ & $68 \%$ & $70 \%$ & 0.496 & $60 \%$ & $42 \%$ & 0.000 & $57 \%$ & $67 \%$ & 0.110 \\
\hline \# Observations & & 532 & 525 & & 404 & 603 & & 161 & 215 & \\
\hline
\end{tabular}




\section{Online Appendix. Assumptions and conversion of monthly household willingness to pay (WTP) to WTP/ton $\mathrm{CO}_{2}$}

To be able to compare the willingness to pay estimates from our study to the social cost of carbon estimates most frequently referenced in the literature, we convert the monthly household willingness to pay to WTP per ton of carbon emissions (dollars/ton $\mathrm{CO}_{2}$ ).

Definitions

$W_{C Y}^{H}=$ WTP per month for a household in country $\mathrm{C}$ and year $\mathrm{Y}$

$H_{C Y}=$ Number of households in country $\mathrm{C}$ in year $\mathrm{Y}$

$E_{C Y}=$ emissions $\left(\mathrm{Mt} \mathrm{CO}_{2}\right)$ in country $\mathrm{C}$ in year $\mathrm{Y}$

$W_{C Y}^{S C C}=$ WTP in country $\mathrm{C}$ and year $\mathrm{Y}$ expressed in dollars/ton $\mathrm{CO}_{2}$

The WTP per ton of carbon emissions (dollars/ton $\mathrm{CO}_{2}$ ) in country $\mathrm{C}$ in year $\mathrm{Y}$ is calculated as the total (annual) estimated willingness to pay divided by the reduction in emissions.

$W_{C Y}^{S C C}=\frac{W_{C Y}^{H} * H_{C Y} * 12}{0.3 * E_{C Y}}$

Note that the reduction in emissions is calculated as the percentage reduction (30 percent) of total emissions for the base year Y (Table O1). The results for the three countries and years are presented in Table A1; monthly WTP values for a 30 percent reduction are obtained from Table 3.

Table O1. WTP in Dollar per Ton $\mathrm{CO}_{2}$ (at a 30\% reduction level)

\begin{tabular}{lcc}
\hline & 2009 & 2019 \\
\hline United States & 18 & 31 \\
Sweden & 85 & 129 \\
China & 11 & 44 \\
\hline
\end{tabular}

\section{Data Sources}

Emissions data from Global Carbon Atlas

Gilfillan, D., G. Marland, T. Boden, and R. Andres, 2019. ”Global, Regional, and National Fossil-Fuel $\mathrm{CO}_{2}$ Emissions.” Boone, NC: Carbon Dioxide Information Analysis Center at Appalachian State University. https://energy.appstate.edu/research/work-areas/cdiac-appstate (accessed September 27, 2019).

UNFCCC (United Nations Framework Convention on Climate Change). 2019. “National Inventory Submissions 2019.” https://unfccc.int/process-and-meetings/transparency-andreporting/reporting-and-review-under-the-convention/greenhouse-gas-inventories-annex-iparties/national-inventory-submissions-2019 (accessed June 11, 2019).

BP. 2019. "Statistical Review of World Energy." https://www.bp.com/en/global/corporate/energy-economics/statistical-review-of-worldenergy.html (accessed June 11, 2019). 
Population data

World Bank. https://data.worldbank.org/country/ (accessed November 16, 2020).

Number of persons per household

Sweden: Data from Statistics Sweden 2019 and 2012. https://www.statistikdatabasen.scb.se/ (accessed November 16, 2020).

United States: Data from https://www.statista.com/statistics/183648/average-size-ofhouseholds-in-the-us/ (accessed November 16, 2020).

China: Data from https://www.statista.com/statistics/278697/average-size-of-households-inchina/ (accessed November 16, 2020). 